\title{
Technology and Innovation Management
}

\section{WORKING PAPER}

\section{Open Global Innovation Networks as Enablers of Frugal Innovation: Propositions Based on Evidence from India}

\author{
Rajnish Tiwari \\ Cornelius Herstatt \\ December 2012 \\ Working Paper No. 72
}

An edited \& peer-reviewed version of this paper has been published as "Frugal Innovation: A Global Networks' Perspective" in: Die Unternehmung, 66(3): 245-274.

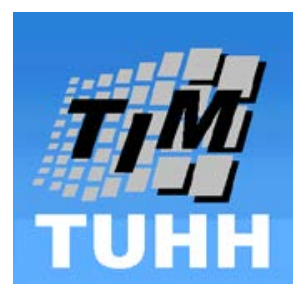

Hamburg University of Technology

Schwarzenbergstr. 95, D-21073 Hamburg, Germany Tel.: +49 (0)40 42878-3777; Fax: +49 (0)40 42878-2867 


\title{
Open Global Innovation Networks as Enablers of Frugal Innovation:
}

\section{Propositions Based on Evidence from India}

\author{
Rajnish Tiwari and Cornelius Herstatt \\ Institute for Technology and Innovation Management \\ Hamburg University of Technology \\ Schwarzenbergstr. 95, 21073 Hamburg, Germany \\ Tel: +49 (0)40 428783776 / Fax: +49 (0)40 428782867 \\ tiwari@tuhh.de / c.herstatt@tuhh.de
}

TIM/TUHH Working Paper No. 72

\begin{abstract}
Summary
Recent years have seen the emergence of low-cost innovations targeted at economically weaker sections of the society, seeking to align business with social welfare. In many instances, results on the ground have been, however, rather sobering as firms have generally (probably justifiably) worried that "good quality, low price" products may cannibalize into their regular business. At the same time those very customers that were intended to benefit from the new approach have tended to shy away fearing low quality and social stigma of using cheap products. Using multiple case studies of successful affordability-driven innovations ("frugal innovations") from India we investigate how firms can effectively reduce market and technology uncertainty of product innovations targeted at price-sensitive customers. The key criteria to success seem to lie in reducing the overall cost of ownership and enhancing customer perception of quality and image. The case studies reveal that affordability-driven innovations are especially successful when firms seek recourse to "open global innovation networks" (OGINs) for collaborative development in all phases of the innovation value chain.
\end{abstract}

\section{Keywords:}

Frugal Innovations, Bottom of the Pyramid, Lead Markets, Open Innovation, Global Innovation, India, Open Global Innovation Networks, Innovation Systems

Note: This working paper is an unedited, authors' version of an academic paper that was published as "Frugal Innovation: A Global Networks' Perspective" in Die Unternehmung, (Swiss Journal of Business Research and Practice), Vol. 66, Issue 03 (2012), pp. 245-274. For the final, edited \& peer-reviewed copy please refer to the published article. 


\title{
1. Introduction
}

\section{"Low-income markets present a prodigious opportunity for the world's wealthiest companies - to seek their fortunes and bring prosperity to the aspiring poor."}

\author{
(Prahalad and Hart, 2002, 2)
}

In a short span of about a decade scholars like C.K. Prahalad, Allen L. Hammond, Stuart L. Hart, Ted London and Vijay Mahajan have played a pivotal role in spreading awareness about the need for, and indeed desirability of, business-driven (profit-motivated) innovations targeted at the bottom of the economic pyramid (BOP), see for example (Prahalad and Hart, 2002, Hammond and Prahalad, 2004, London and Hart, 2004, Prahalad, 2005, Mahajan et al., 2006, Mahajan, 2009, London and Hart, 2010). These path-breaking efforts and other scholarly works that have followed, such as (Ireland, 2008, Gupta, 2010, Ramani et al., 2010, Venn and Berg, 2011), have successfully established that economically weaker and disadvantaged sections of the society too can act as a rich source of innovative ideas. Catering to their needs can help firms gain (and/or retain) a competitive position.

This shift in paradigm has also attracted some thought-provoking criticism centering on the fear that targeting the poor as consumer might lure him (or her) into "wasting away" the precious little resources at his disposal, on goods and services unnecessary, and in some instances even detrimental, to his own welfare (Karnani, 2007a, 2009). ${ }^{1}$ The basic idea, however, remains justifiably positive in that it can potentially make significant contribution in raising the standards of living for millions, even if not billions, of people as proven by several examples such as iodized salt or mobile payment services (cf. WEF, 2009).

Nevertheless, the promised fortunes for "the world's wealthiest companies" and "prosperity to the aspiring poor" (Prahalad and Hart, 2002), have remained elusive to some extent as economic success of many a BOP venture in terms of market penetration and customer acceptance has been less than spectacular. Ted London has attributed this to a lack of robust information gathering and assessment system: "[...] it's been nearly impossible to gauge the efficacy of these ventures. Businesses, nonprofits, and other organizations that deliver products to and purchase goods from the base of the pyramid usually don't have robustenough systems to accurately assess how well they're reaching the people they set out to serve [...]" (London, 2009, 107).

Critics have been somewhat "harsher" in their judgment. Several evaluations suggest that on the enterprise side too there are significant impediments hindering firms' capability to cater to the market needs of BOP under given inherent structural deficits. For instance, Karamchandani et al $(2011,107)$ contend that barring a few exceptions concentrated in a

\footnotetext{
${ }^{1}$ In this respect Aneel Karnani (2007a) cites as one example the case of "Fair \& Lovely" skin whitening cream, which, probably with some justification, may be suspected of trying to cash on discriminatory social practices. The greater issue involved here, however, is of a specific social mind-set and a consumer's free and individual choice regarding a product legally produced and sold. Preventing "undesirable" consumption, if at all a decision to be taken by third-parties and not an adult individual on his or her own behalf, must be left to the State, which through its constitutionally legitimized source of authority may employ a combination of regulatory tools (such as tax incentives or licensing mechanisms) and educational measures to influence certain consumption patterns in its spheres of political and regulatory influence.
} 
few industries such as telecommunications, fast-moving consumer goods (FMCG), and pharmaceuticals, global corporations "have been largely unable to reduce costs and prices enough to serve poor consumers". One reason for this difficulty may lie in the relatively small size of BOP markets when measured in market exchange rates (Karnani, 2007b). Another reason could be rooted in the fear to "cannibalize the existing market for expensive technology" that reportedly plagues many Western firms (Economist, 2012). At any rate, Karnani's examination of several published examples of BOP innovations came to the conclusion that "success stories of selling to the poor" are rather "isolated instances" as many BOP products were found to be priced much higher in comparison to their nonbranded competition (Karnani, 2007b: 96). It has been suggested that merely "removing features from existing products to sell them cheaper in emerging markets is a losing game. That's because emerging market customers have unique needs that usually aren't addressed by mature-market products, and because the cost base of developed world products, even when stripped down, remains too high to allow competitive prices and reasonable profits in the developing world" (Sehgal et al., 2010: 21).

This assertion is supported by some noteworthy factual evidence. There have been instances of successful affordability-driven innovations in emerging economies, that have even went on to succeed globally, e.g. the a baby-warmer called "Lullaby" developed by GE in India, which is now reportedly sold in 62 nations (Mahalakshmi, 2011), small-sized tractors developed by India's Mahindra \& Mahindra and now sold in the USA (Economist, 2012), or an Algae-bacteria based wastewater treatment system developed by Siemens in India, which requires about only $40 \%$ energy for treating wastewater than a conventional sewage treatment plant (Dachs et al., 2012). Such innovations have been defined as being "frugal" for they focus on focusing on the elementary, core-functionality and renounce integrating unnecessary features. The purpose is to reduce not just the selling price but also the overall cost of operation (Tiwari and Herstatt, 2012a). This is however not achieved by strippingdown of existing products but rather by starting from the scratch: "frugal engineering is an overarching philosophy that enables a true 'clean sheet' approach to product development. Cost discipline is an intrinsic part of the process, but rather than simply cutting existing costs, frugal engineering seeks to avoid needless costs in the first place" (Sehgal et al., 2010: 21). An interesting aspect of frugal innovations, as indicated by involvement of some multinational firms and their affiliates in the developing world, seems to be that they often take place in "Open Global Innovation Networks" (OGINs) and contribute to ensuring quality and reducing costs (Tiwari and Herstatt, 2012a).

The discussion above shows an interesting research gap: While on the one hand, the traditional BOP approach reports a mixed performance, the emerging phenomenon of (affordability-driven) frugal innovations seems to succeed in overcoming barriers to market and technology uncertainty. This paper investigates how firms can reduce market and technology uncertainty inherently presented in product innovations targeted at pricesensitive customers. For this purpose, three propositions will be developed and examined in the light of six selected case studies of frugal innovations from India.

The paper is structured on the following lines: After this brief introduction, we define frugal innovations and their conceptual framework in section 2, while section 3 defines OGINs and their possible connection to frugal innovations. These two sections build the cornerstone for the literature review and serve as a basis for deriving our propositions, which are then 
examined in section 4 by the means of six case studies. Discussion and implications of the research are presented in section 5. Finally, section 6 entails a summarizing conclusion. For the purpose of this paper we work with definitions of the terms "innovation" and "research and development" (R\&D) that are based on the OECD guidelines contained in the Oslo Manual (OECD, 2005) and Frascati Manual (OECD, 2002), respectively.

\section{Frugal Innovation: A Conceptual Framework}

The term frugal innovation refers to innovative products and services that "seek to minimize the use of material and financial resources in the complete value chain (development, manufacturing, distribution, consumption, and disposal) with the objective of reducing the cost of ownership while fulfilling or even exceeding certain pre-defined criteria of acceptable quality standards" (Tiwari and Herstatt, 2012a).

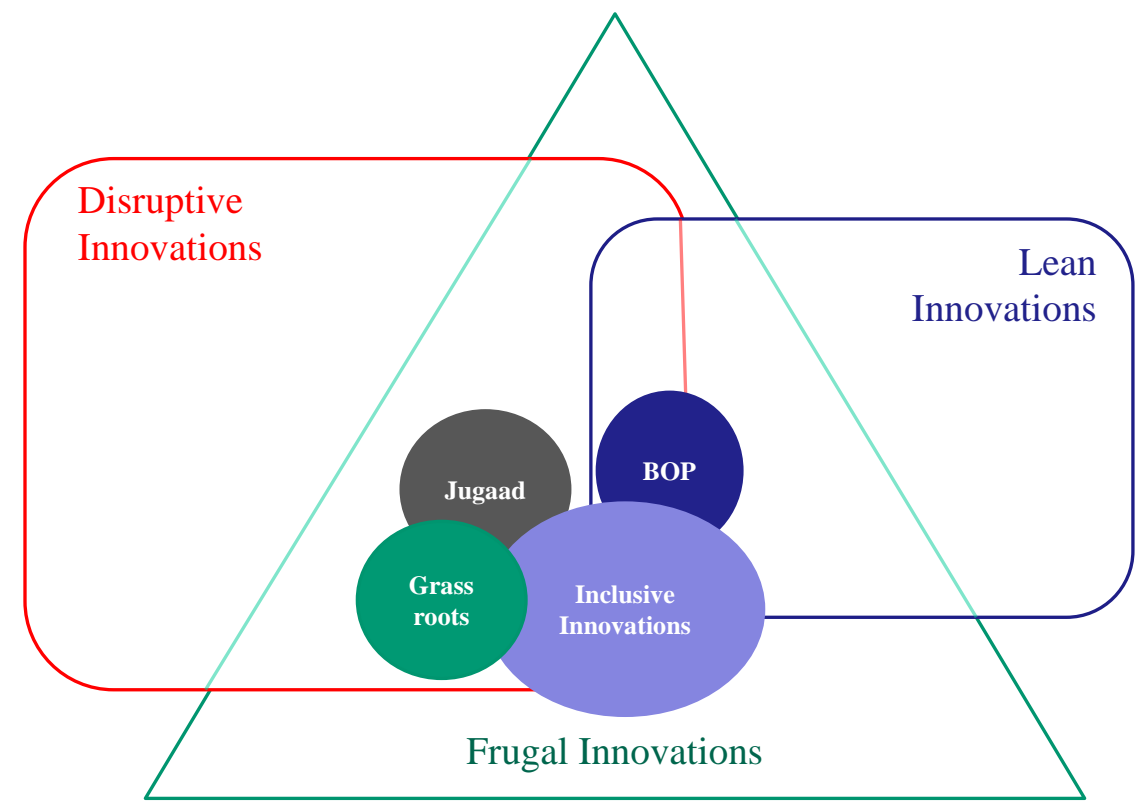

Figure 1: Context of Frugal Innovations ${ }^{2}$

Frugal innovations share several, though not all, characteristics with the various other related terms as characterized in Figure 1 and explained in the following:

Frugal Innovations tend to have a disruptive character (cf. Christensen and Raynor, 2003), as they often involve a new business model, which seeks to reach out to the group of pricesensitive and hitherto unserved consumers (den Ouden, 2012). However, they do not necessarily signify a business model that "picks off the least attractive customers of established firms" (Christensen and Raynor, 2003: 46), as is probably best exemplified by the concerted efforts of many global carmakers to wrest away market share from Maruti Suzuki in India, which primarily serves cost-sensitive customers. Moreover, frugal innovations can have a sustaining effect for the business of an incumbent already engaged in serving this customer segment, as is again best exemplified by Maruti Suzuki and the Tata Group of India. Innovations by the Indian Space Research Organization (ISRO) also illustrate the point

\footnotetext{
${ }^{2}$ Source: Authors' illustration
} 
in that these are frugal innovation but not necessarily always disruptive in nature (Tiwari and Herstatt, 2012b, a).

Frugal innovations tend to share several characteristics with "lean" innovations that seek to work "efficiently with knowledge" to turn it faster into "value" (Sehested and Sonnenberg, 2008). According to Schuh et al. (2011) one of the core element of Lean Innovation lies in defining, structuring and prioritizing "values" for specific innovation projects. While frugal innovations undoubtedly seek to rationalize the innovation value chain, their objectives might differ considerably. Whereas the end outcome of a lean innovation project need not necessarily be a low-cost product, it takes much more than efficient management of the innovation process to come up with a successful disruptive, game changing innovation.

Frugal innovations can fully encompass the key characteristics of individual related terms such as "Jugaad", "Grassroot Innovations", "Bottom of the Pyramid" with its various variants, and "Inclusive Innovations" (Gupta, 2010, Singh et al., 2011). For reasons of space, it probably suffices to say that the term frugal innovation can act as an integrating mechanism to bring these various concepts under one umbrella. A key difference to essentially cost-driven (BOP oriented) approaches lies in the fact that frugal innovations are not necessarily targeted at the very bottom of the economic pyramid. Rather, they seek to address customers that, by compulsion or choice, seek products whose overall cost of ownership is placed significantly below standard (entry level) products. Needs of such customers have been often left unserved so far. The inherent characteristic of frugal innovations lies in its value proposition that enables robust and good quality able to cope with given infrastructural difficulties while reducing the cost of ownership for the customer. "The potential customer should not only actually possess the means to pay for the product. Rather, he should be also willing to spend his scarce resources on that particular product. Because the company is mostly competing against non-consumption"(Tiwari and Herstatt, 2012a). Simultaneously, the product should possess volume-potential to enable sufficient profit incentives despite thin margins.

The difference to other concepts is noteworthy because one major issue affecting conventional BOP markets has been that of quality perceptions and image concerns of those very people, whom the firm intends to serve. Whilst firms have generally worried that highquality, low-priced products may eat away into their regular business (Karamchandani et al., 2011, Economist, 2012), customers have generally acted in a reserved manner while accepting products that were specifically designed and marketed as "low-cost products" as the example of the world's cheapest car, The Tata Nano, has documented (Dhume, 2011). The Tata Nano's sales have so far fallen behind the immensely high expectations created by unprecedented media hype surrounding the Nano's development and launch. According to one estimate, the Nano brought Tata Motors worldwide publicity worth \$220 million (cf. Palepu et al., 2011). Yet, one report in the Financial Times quoted an executive from a rival carmaker as stressing: "Nobody wants to buy the world's cheapest car" [emphasis added] (Fontanella-Khan and Munshi, 2011). In fact, Ratan Tata, chief of the Tata Group, explicitly recognized this challenge while launching the Tata Swach, a low-cost water filter from the Tata Group. Speaking at the launch, Mr. Tata took pains to emphasize that the quest was not to create the cheapest products but to reach the largest number of people (Economic Times, 2009). Prof. Anil Gupta, Executive Vice Chairman of India's National Innovation Foundation, who has done extensive work to promote grassroot innovations too has been quoted as 
saying that "[p]eople still feel that good technology still comes from abroad" (Malhotra, 2009), which inter alia confirms that potential consumers are plagued by quality concerns, real or imaginary.

Studies suggest that BOP consumers, despite income constraints, seek sophisticated products that do not carry the stigma of being a poor people's product. A cross-country study of products and services targeted at BOP consumers in Asia, Africa, and Latin America, discovered that these are "motivated not just by survival and physiological needs but seek to fulfill higher order needs either to build social capital, for cultural reasons or as a compensatory mechanism" (Subrahmanyan and Gomez-Arias, 2008). Some other studies, such as (Tiwari and Herstatt, 2012b), have also suggested that merely "stripped-down" versions of existing products and technologies fail to "match the aspirations of the potential customers". Success of low-cost cars of Maruti Suzuki have been rather a result of their image as "good quality products for affordable price" (Tiwari and Herstatt, 2012b).

Based on this discussion, we propose that:

Frugal innovations have a greater chance of commercial success if their value proposition incorporates the twin objectives of reducing the cost-of-ownership while matching customer aspirations for quality and image.

\section{Open Global Innovation Networks as Enablers for Frugal Innovation}

\subsection{Connecting Open to Global Innovation}

One way to achieve the twin objectives of offering quality products at an attractive cost-ofownership seems to be in making best possible use of opportunities of "open innovation" (cf. Chesbrough, 2003, 2006) on a global scale, as suggested by some recent studies (Tiwari and Herstatt, 2012b, a). "Open innovation is a paradigm that assumes that firms can and should use external ideas as well as internal ideas, and internal and external paths to market, as firms look to advance their technology (Chesbrough et al., 2008, vii). Open innovations are not only concerned with sourcing of external knowledge into the firm ("outside-in") but also with exploring new channels of revenue generation by granting usage rights (joint ventures, licensing or outright sale) of in-house developments to other firms ("inside-out"), "especially when the technology has future potential but is not part of the firm's core strategy" (OECD, 2008b, 11). While the original perspective of innovation primarily focused on research and development of firms, open innovation has outgrown this narrow view and today integrates more and different streams and perspectives (Gassmann et al., 2010). One of these "new" streams contributing to open innovation and vice versa includes globalization of innovation and in this realm the context and aspects of frugal innovation.

\subsection{Enhancement of Value Proposition}

The rationale for this development is twofold:

(i) Frugal innovations, even though often disruptive in nature, stand to benefit from new applications of existing technologies after modifying them in a suitable 
manner. Kodama $(1992,70)$ has referred this approach of "combining existing technologies into hybrid technologies" as "technology fusion", which grows out of long-term R\&D ties between multiple companies spanning across several industries (Kodama, 2012). As Kalogerakis et al. (2010, 418) put it: "[...] organizations pursuing innovation usually make use of already existing ideas, knowledge, and experience. The 'new' in a new product is very often a novel combination of elements from existing knowledge bases that have not previously been connected". Frugal innovators are less likely to stubbornly re-invent the wheel and may be more open to looking for analogies in other fields including low cost solutions.

(ii) Scientific progress, growth in educational standards and the ongoing economic development in many countries (for instance, the BRIC countries that denominate Brazil, Russia, China and India) have created favorable regional and national systems of innovation (OECD, 2008b, Buse et al., 2010). While globalization has reduced barriers of cooperation, technological development, especially in the field of information and communication technologies (ICT), have reduced barriers of distance. Foreign direct investments (FDI) have opened access to global knowhow within internal boundaries of the firm (OECD, 2008a). Even small and medium-sized firms today are able to benefit from " [...]market and nonmarket spillovers, which, in turn, has raised local endogenous innovation and productivity growth." (Islam, 2010)

Therefore, it seems logical that frugal innovations are best fostered when the sectoral and national systems of innovation in a given location not only enable cost advantages for R\&D and manufacturing, but also are endowed with access to open innovation networks in national and international context (Tiwari and Herstatt, 2012b). The cooperation may take place at any stage of the innovation process, which incorporates the whole innovation value chain starting at idea generation and assessment, and ends with successful market introduction (Herstatt and Verworn, 2004). Figure 2 shows a classification framework for open global innovation networks (OGINs). 


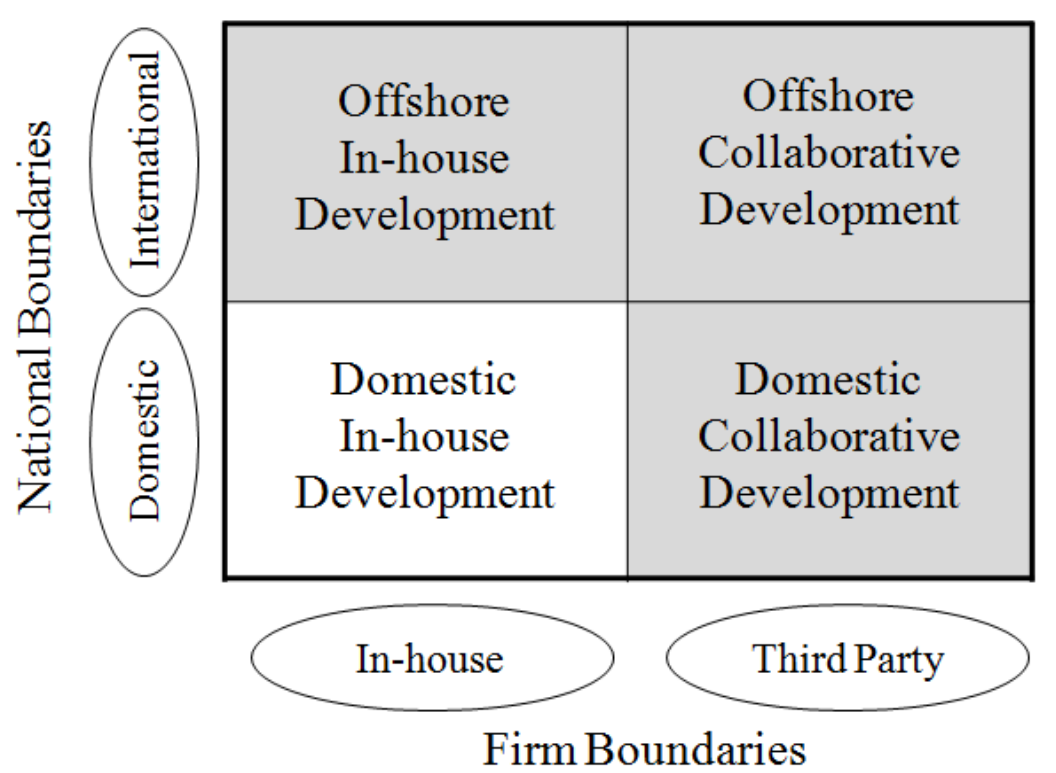

Figure 2: A Framework for Open Global Innovation Networks ${ }^{3}$

This network is basically built on two dimensions that depict firm and national boundaries, respectively. Whilst firm boundaries are defined in terms of legal independence of an enterprise, national boundaries, as used here, refer to international geographic entities that routinely administer their own affairs irrespective thereof, whether or not they enjoy political sovereignty in terms of international law. ${ }^{4}$ The shaded cells represent what we define as an OGIN, which we would like to describe briefly in the following:

Offshore Collaborative Development (OCD) takes place when a firm collaborates with thirdparty providers of product development services and/or other external partners that are outside the firm's own formal boundaries and located outside of its home base.

Domestic Collaborative Development (DCD) takes place when a firm collaborates with thirdparty providers of product development services and/or other external partners that are outside its own formal boundaries but located in the same country where the firm has its home base. Such partners need not necessarily be domestic firms. Rather, they might also be affiliates of multinational companies (MNCs). In a country like India we find numerous instances of domestic collaborative development between firms of various "nationalities" engaged in business in their host country. For this reason, it seems appropriate to include this form of collaboration in the "global" network, despite it being located in the same country.

Offshore In-house Development (OID) is treated here as a special form of open innovation, even though strictly speaking the product development takes place within the formal boundaries of the firm. However, this would fail to take into account that many overseas acquisitions, especially those by emerging country multinationals, are of a recent nature and in many instances the very reason for their take-over is the desire of the acquirer to seek

\footnotetext{
${ }^{3}$ Source: Authors' classification modelled after (van Welsum and Vickery, 2005, OECD, 2008a)

${ }^{4}$ For instance, for the purpose of this paper Hong Kong, China and Taiwan would constitute 3 different entities.
} 
access to the latter's technology and intellectual property. Insofar it may be argued that the know-how being employed has not been developed by the incumbent.

These three collaborative forms of product development are thus, for the purpose of this paper, defined as OGIN. One key criterion for an OGIN is that the process of product development should transcend at least either the firm boundary or the national boundary. For this reason, the fourth form of product development, namely the Domestic In-house Development (DID) is excluded from OGINs since it transcends neither the formal boundary of the firm nor that of the nation.

Our second proposition is that:

Companies can increase the probability of offering an attractive value proposition for successful frugal innovations if they are able to successfully connect their product development process with global innovation networks.

\subsection{Role of Lead Markets in Enabling Access to OGINs}

Lead markets characterize a country where an innovation is first widely accepted and adopted (Beise, 2004). To some extent they can be compared with "lead users", who face needs today that most customers in the market will probably face tomorrow (Herstatt and von Hippel, 1992). The successful diffusion of the innovation in a lead market sends a positive signal to consumers elsewhere (Bartlett and Ghoshal, 1990, Beise, 2004). The reason is that users in some countries, due to their given socio-economic or geographic conditions, perceive greater benefits in adopting a product at an early stage and are therefore more receptive to (technological) change. The innovation, once successful, trickles down to other regions. One example for such an innovation is the fax machine, which was first widely accepted in Japan and then diffused globally (Beise, 2004). The trickling down effect is therefore rooted in the competitive advantage (e.g. anticipatory needs) enjoyed by the lead market country (Porter, 1990). Anticipatory needs can deliver valuable inputs for the innovation process of a firm regarding future developments and thereby reduce market and technology uncertainty (Gerybadze, 1997), which is "particularly important in the early stages of innovation projects" (Lüthje and Herstatt, 2004: 553). Therefore, such markets are regarded a precious source for innovative ideas. For this reason firms often prefer to establish their R\&D facilities in lead markets (Gerybadze and Reger, 1999, Sachwald, 2008). While lead markets have been traditionally thought to exist almost exclusively in industrialized and economically developed countries, some recent studies, e.g. (Herstatt et al., 2008, Tiwari and Herstatt, 2012b, a) have suggested that lead markets can also emerge in developing economies such as India.

With specific regard to India, it has been suggested that it has evolved into a hub for frugal innovations (Prahalad and Mashelkar, 2010, Govindarajan and Trimble, 2012, Radjou et al., 2012, Tiwari and Herstatt, 2012a). More broadly, a developing country lead market, on account of its cost arbitrage, enjoys a crucial and inherent advantage in respect of ("lowcost, thin-margin") frugal products. Low costs of manufacturing enable local production. This in turn strengthens local R\&D capabilities required to support the production process. Process innovations emanating from local R\&D create a virtuous cycle by improving the quality of local production. Additionally, this country has generally already established a 
base of science and technology that enables access to (global) open innovation networks within the country and helps to upgrade the R\&D capabilities by creating "cross-border nodes between regional/national systems of innovations" (OECD, 2008b, 11). Finally, innovators in the local lead market enjoy first-hand implicit knowledge of frugal markets and the social mind-set ("social capital"). Purely subject-specific expertise, devoid of relevant first-hand experience, would face handicap in implementing frugal innovations.

Companies, pursuing the strategic intent of serving markets for frugal innovations, should seek access to specific lead markets that are endowed with such open innovation networks. Frugal innovations are best located in lead markets. Parallel development: individual entrepreneurs and firms can continue their efforts in decentralized manner, whereas corporate houses and the formal sector would be well advised to concentrate their product development efforts in selected lead markets. This leads us to our final proposition:

Setting up innovation capabilities in product-specific "lead markets" increases the probability to identify and access suitable global innovation networks.

\section{Examples of Frugal Innovations from India}

\subsection{Methodology}

Case studies are thought to be particularly useful, when dealing with the "why" and "how" aspects of enquiries, especially in regard to real-life phenomena still in the process of emerging (Eisenhardt, 1989, Yin, 2003). Specifically, studies with multiple cases are regarded to be "a powerful means to create theory because they permit replication and extension among individual cases" (Eisenhardt, 1991, 620). In this section we briefly describe six cases of frugal innovations, which except for the Tata Nano case are drawn from (Tiwari and Herstatt, 2012b, a). The cases have been selected in a way that they, apart from generating insights related to the three propositions made above, fulfill some additional criteria. For example, one primary selection criterion has been that they the innovations in questions have been already commercialized and can be considered to have had a positive effect on social welfare ("greater good"). Second, they should have contained at least some elements of OGINs during their innovation process. Third, they as a group are selected to represent a wide spectrum of multiple industries, intra-industry segments and entrepreneurial types. To illustrate it with one example, the Tata Nano represents the segment of low-cost passenger cars, while the example of the Tata Ace represents the segment of professional truck-drivers, who were earlier dependent on less-safe 3-wheeler goods carriers. Electronic voting machines (EVMs) are a product of government institutions' collaboration with state-run public-sector enterprises. The battery-run ChotuKool fridge and the water filter Tata Swach represent two cases of consumer goods, while the solar-powered ATMs of Vortex are directed at business customers, i.e. banks. Also, the cases allow a good degree of variation between firm size and operations. While the two Tata Group companies are part of a large conglomerate operating at a global level, manufacturers of EVMs are large, public-sector firms with domestic focus (even though exporting), and Vortex is a medium-sized firm. For reasons of space the case studies are kept concise and intend to basically highlight two 
aspects: welfare effects and the collaborative effort in the innovation process. ${ }^{5}$ These two innovation aspects (welfare effect and collaborative effort) are directly related to the three propositions proposed above, as explained below:

(a) Reducing the cost-of-ownership while matching customer aspirations for quality and image reduces the potential resistance to innovation by prospective customers and increases the chances of successful diffusion (Ram and Sheth, 1989). A favorable value proposition can be achieved by utilizing synergies between different players from various business and technology fields.

(b) Access to OGINs can be considered supportive for "technology fusion" (Kodama, 1992) or product/technological analogies (Kalogerakis et al., 2010) that may help reduce the cost of product development and increase product affordability. This would, as a result, strengthen the welfare effect of innovations. OGINs, per definition, represent collaborative effort and reduce market and technology uncertainty in product developments on account of a shared and vast knowledge base and proven technologies in the portfolios of the partners.

(c) Lead markets have a large base of (domestic) demand and are endowed with significant price \& cost advantage (Beise, 2004). They can help reduce cost of production enabling greater affordability for resource-constrained customers. Lead markets are also characterized by a high degree of concentration of firms and supporting industries (Porter, 1990, Gerybadze and Reger, 1999). The sheer presence of competent potential partners increases the possibility of forging collaborations.

The relation of the three propositions to these two effects is shown in Table 1:

\begin{tabular}{|c|c|c|c|}
\hline \multirow{2}{*}{$\begin{array}{c}\text { Aspects of Case } \\
\text { Studies }\end{array}$} & Proposition I & Proposition II & Proposition III \\
\hline & $\begin{array}{l}\text { Cost-of-Ownership/ } \\
\text { Customer Aspirations }\end{array}$ & Access to OGINs & $\begin{array}{c}\text { Engagement in Lead } \\
\text { Markets }\end{array}$ \\
\hline (A) & (B) & (C) & (D) \\
\hline Welfare Effect & $\begin{array}{l}\text { - Favorable value } \\
\text { proposition } \\
\text { increases } \\
\text { probability of } \\
\text { production } \\
\text { adoption/ diffusion }\end{array}$ & $\begin{array}{l}\text { - Use of "technology } \\
\text { fusion" \& analogies } \\
\text { to create cost- } \\
\text { effective solutions }\end{array}$ & $\begin{array}{l}\text { - Lead markets have } \\
\text { large demand-size } \\
\text { and enable } \\
\text { economies of scale } \\
\text { (cost-reduction) }\end{array}$ \\
\hline Collaborative Effort & $\begin{array}{l}\text { - Favorable value } \\
\text { proposition can be } \\
\text { achieved by utilizing } \\
\text { mutual synergies }\end{array}$ & $\begin{array}{l}\text { - OGINs help reduce } \\
\text { market and } \\
\text { technology } \\
\text { uncertainty }\end{array}$ & $\begin{array}{l}\text { - Greater } \\
\text { concentration of } \\
\text { firms and supporting } \\
\text { industries enable } \\
\text { access to OGINs }\end{array}$ \\
\hline
\end{tabular}

Table 1: Research positions and their relation to welfare effects and collaborations

\subsection{Small Car: Tata Nano}

The Tata Nano, with an initial market introduction price of Rs. 100,000 (approx. $\$ 2,000$ in then exchange rates), is widely regarded as the cheapest car of the world (Schuster and Holtbrügge, 2011). Launched by Tata Motors Ltd. (TML) amid much fanfare in March 2009,

\footnotetext{
${ }^{5}$ All figures related to Indian fiscal years (FY) refer to the period from April of a given calendar year to March of the following year. All dollar figure (\$) relate to US dollar.
} 
the Nano concept car was first unveiled in January 2008 at Delhi AutoExpo (Chacko et al., 2010). The driving idea behind the Nano has been group chief Ratan Tata's vision of providing a safe and comfortable medium of transport to millions of Indian families that use two-wheeled vehicles to travel with their family (spouse and children) of 4-5 persons under extreme weather conditions in summer, winter and during monsoon (Palepu et al., 2011). Two-wheelers are the main medium of transport in India, where they account for $76 \%$ of all motor vehicles, as opposed to $16 \%$ share of four-wheeled passenger vehicles. In FY 2010-11, close to 11.8 million two-wheelers (and 2.5 million passenger vehicles) were sold in India (SIAM, 2012).

Post-launch, the Nano has been however widely perceived to have failed in the market. Its sales were marred by safety concerns generated due to some isolate incidences of the vehicles catching fire and the stigma of being "the cheapest car on the block". ${ }^{6}$ Nevertheless, objectively speaking, the Nano cannot be regarded a failure, even though its sales figures have not yet satisfied the forecasts by marketing pundits and enormous expectations of various stakeholders. Data by Society of Indian Automobile Manufacturers (SIAM) reveal that the launch of the Tata Nano has actually succeeded in arresting the slip in the market share of India's mini-sized cars (length not exceeding 3,400 mm), as can be seen in Figure 3 .

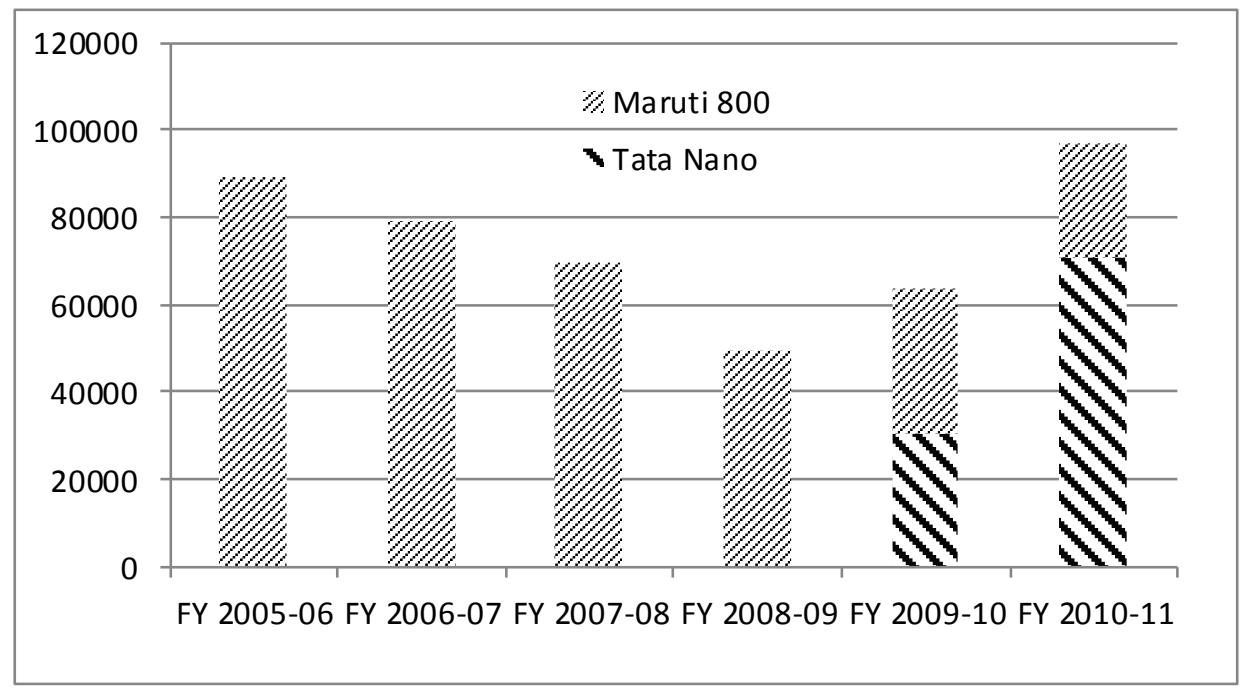

Figure 3: Domestic sales in India's Market for Mini Cars (in numbers) ${ }^{7}$

In FY 2011-12, the Nano saw a growth of 6\%, selling 74,527 units (TML, 2012b). For the first time, it also started to meet overseas demand, exporting 1,125 units in the first six months of FY 2011-12 (SIAM, 2012). Recent reports quoting car dealers have suggested that TML's efforts to address the safety concerns, enhance the exterior design, and improve fuel efficiency has helped the Nano attract women and first-time buyers, even as SIAM reported the Nano's monthly sales having risen to nearly 10,500 units trebling between October 2011 and March 2012 (Mohile, 2012). Since the market leader, Maruti Suzuki, has been slowly phasing out the Maruti 800, its flagship in the segment for mini cars, the segment had been

\footnotetext{
${ }^{6}$ Two different investigations by internal and independent international experts found that the incidences had been caused by inappropriate handling and re-affirmed the technical robustness of the car (Thakkar, 2010, TML, 2010b). Nonetheless, TML took various technical and promotional measures to reassure the customers.

${ }^{7}$ Source: Authors' illustration based on (SIAM, 2012)
} 
shrinking over the course of time, as customers shifted to compact cars (length between 3,401 and $4,000 \mathrm{~mm}$ ). It is obvious that the entry of the Nano has rejuvenated the market and allowed many first time buyers to purchase a safer and more comfortable means of transportation than a 2-wheeler.

TML's top management decided to implement "concurrent engineering in real time" by integrating component suppliers very early on in the process of product development (Gupta, 2008), and about 800 component suppliers were approached. Rather than providing them with pre-defined technical specifications, TML extended an invitation to contribute their own ideas for this unique project. About $70-80 \%$ of the suppliers decided to participate in the product development process (Palepu et al., 2011). TML also tapped suppliers of twowheelers in order to identify possible analogies and synergies. In a significant departure from the norm, more than half of all the components sourced were allowed to be developed as proprietary technology of the respective supplier to enable tapping of other sources of revenue and thus further reduce costs. Companies like Bosch have already made use of this opportunity by transferring components to other carmakers. Apart from Bosch, several domestic and global suppliers, such as Continental AG, Denso, Sona Group and Tata Johnson Controls Automotive contributed to the Nano project with their own radical innovations.

Final touches to the car were given by Italy's renowned Institute of Development in Automotive Engineering (I.D.E.A.). According to TML's Annual Report for FY 2010-11 technology for development and application of a two cylinder common-rail diesel engine for small passenger cars (and small commercial vehicles) was imported from overseas (TML, 2011). Similarly, technology for "[d]esign and [d]evelopment of [i]nfinitely variable transmission based on full toriodal traction-drive variators for various vehicle platforms" has been imported (TML, 2011).

TML also established a European Technical Centre in UK in 2005. This centre is entrusted with the task of providing "[e]uropean and international standards of delivery to the company's passenger and light commercial vehicles" (TML, 2012a). For keeping the production cost low, important suppliers have been co-located in the vicinity of the manufacturing plant to reduce inventory and logistics costs.

\subsection{Small Commercial Vehicle: The Tata Ace}

The "Tata Ace" is a small commercial vehicle (SCV) with a payload capacity of 0.75 tons that was launched in 2005. While meeting all safety requirements, it came with a price-tag of approx. $\$ 5,000$ that is about $50 \%$ less than any other four-wheeled commercial vehicle in India. The Ace has been conceived as a "cheap, nasty and rugged vehicle for India" (Palepu and Srinivasan, 2008), with "low-cost, low-maintenance" features that would be ideally suited for India's narrow and crowded roads, as well as for long highway journeys (Singh and Chaudhuri, 2009, Khanna and Palepu, 2010).

The product was primarily conceived as a substitute for three-wheeled commercial vehicles. TML reportedly interviewed more than 4,000 truck and three-wheeler operators in rural and urban areas of India as part of its voice-of-the customer analysis (Palepu and Srinivasan, 2008). It was discovered that the potential customers "were looking for a vehicle that offered the price, fuel efficiency, and maneuverability of a three wheeler but with the safety, durability, additional payload, and comfort of a four-wheeled truck". 
"By offering a niche vehicle that met the unique needs of the Indian transportation sector at a price comparable with that of a three wheeler, the Ace created an entirely new product category". The Ace has proved to be an immense success, generating a brand value of about $\$ 175$ million within one year (cf. Singh and Chaudhuri, 2009). The $100,000^{\text {th }}$ Ace rolled out within only 22 months of the launch (TML, 2007). It has created a new market of SCVs that was non-existent till then. While it originally intended to attack the three-wheeled commercial vehicles market by providing better safety and comfort to drivers at affordable prices, about $54 \%$ of customers have been actually found to be non-consumers purchasing their first commercial vehicle (Palepu and Srinivasan, 2008).

TML, which has a long history of in-house technical capabilities, often involves external stakeholders from within and outside the Tata Group of companies (Mishra, 2012). For example, gas injection technology for Tata Ace was procured from Alternative Fuel Systems Inc. (AFS) of Canada (TML, 2010a). In production too, unusually high $81.5 \%$ of contents were outsourced with the objective "to convert the fixed cost of production facilities into variable costs" (Palepu and Srinivasan, 2008: 11).

\subsection{Electronic Voting Machine}

Electronic Voting Machines (EVMs), as used in India are "a simple electronic device used to record votes in place of ballot papers and boxes which were used earlier in conventional voting system" (GOI, 2009: 181).

Usage of EVMs in India was first mooted by the Election Commission of India in 1977 "to save avoidable and recurring expenditure on printing, storage, transportation and security of Ballot Papers to the exchequer" (GOI, n.d.). By 1979 a prototype was developed in collaboration with the public-sector Electronics Corporation of India Ltd. (ECIL). The intention was to design "a simple electronic machine that is reliable, easy to operate and difficult to manipulate" (Verma, 2005: 370). After securing a broad political consensus another public-sector entity Bharat Electronics Ltd. (BEL) was co-opted in the consortium. After a somewhat lengthy political and legal process of granting EVMs a legal status with broad acceptability, the Election Commission of India in 2004 decided to use EVMs in all elections at all polling stations of the country. In the national elections held in 2004, EVMs were used for the first time through-out the country and could save the usage of about 8,000 tons of paper required for printing ballot papers and thereby also saved around 150,000 trees. The Election Commission estimates that the usage of the EVMs would save roughly 10,000 tons of ballot paper (and nearly 200,000 trees) in each of the future national elections alone. EVMs have increased the number of voters per booth from 1200 to 1500 thereby freeing up resources for better organization while reducing incidences of poll rigging and invalid votes in a very significant manner.

EVMs are supplied to the Election Commission of India at a price of Rs. 8,670 per unit (ECIL, 2010: 38) which translates to approx. $\$ 168.52 .{ }^{8}$ Whereas India has been able to implement an effective and highly accepted e-voting with EVMs costing all in all approx. \$200 million, a similar project in the United States has been budgeted with more than \$2 billion for distribution to states for the purchase of new voting machines and other related measures (FEC, 2004). Impressed by the low-cost and reliable functionality of EVMs several other

\footnotetext{
${ }^{8}$ Using an exchange rate of $\$ 1=$ INR 51.4478 as on 16.01.2012.
} 
nations have shown interest in using it. Whereas Nepal and Bhutan have already started using India-manufactured EVMs, several other countries, such as Fiji, Kenya and Namibia are reportedly interested in employing EVMs in their respective elections (Tiwari and Herstatt, 2012b).

\subsection{Battery-driven Fridge: ChotuKool}

"ChotuKool" is a compact and portable low-cost cooling solution of the firm Godrej \& Boyce and was commercially launched in 2010 for a price tag of approx. \$75. It is equipped to operate on battery or an inverter to cope with the erratic power supply prevalent in many parts of India. The product uses high-end insulation to stay cool for 2-3 hours without power, while its small size (1.5 X 2 feet) caters to constraints of small living spaces. It is lowweighted to ensure portability since many of ChotuKool's potential owners live in small oneroom dwellings and household items have to be shifted every evening to make sleeping space (Whitney, 2010). At launch, ChotuKool was about 50\% cheaper than the next entrylevel fridge available in the market that are endowed with much greater storage capacity than required by the targeted customer group (Bellman et al., 2009, Kumar, 2009, Chakravarthy and Coughlan, 2011). The operational cost of ChotuKool is kept low as it requires about half the power consumed by regular refrigerators.

Ethnographic research had revealed that the targeted customers didn't need full-scale refrigerators. They only required limited storage which would save milk, vegetables and leftovers from spoilage for a day or two (Eyring et al., 2011). At present, less than $18 \%$ of all households in India possess a refrigerator (Whitney, 2010). The penetration level, especially in rural and semi-urban areas, is even lower. On the other hand, an estimated "one third of India's food is lost to spoilage because of a combination of frequent power cuts, heat, and high humidity" (Chakravarthy and Coughlan, 2011: 31).

ChotuKool employs thermoelectric cooling, developed by Jean-Charles Peltier, a French national, in the first part of the $19^{\text {th }}$ century, which was, however, never employed to serve a low-cost cooling solution. It is a product of "co-creation". The idea of a small-sized, batterypowered and affordable means of refrigeration for a vast majority of non-consumers was created by Godrej in collaboration with Innosight (Anthony, 2012, Godrej, 2012), a global innovation and strategy consulting firm located in Boston (USA), Singapore and Bangalore (India) and co-founded by Prof. Clayton M. Christensen, a renowned proponent of disruptive innovations (Innosight, 2012). ChotuKool was developed in close interaction with the targeted customer groups "to get insights on their needs, desired solutions and barriers to consumption" (Godrej, 2012). It is distributed by villagers (and other social entrepreneurs) who have been trained as salespersons (Kumar, 2009, Godrej, 2012). They earn a commission of roughly $\$ 3$ per fridge sold, while enabling Godrej to cut down its marketing and distribution costs by $40 \%$ (Chakravarthy and Coughlan, 2011: 31). Through collaboration with the Indian Postal Department, e.g. in Gujarat state, the fridge can be ordered at the local post office and is then shipped within one week directly to the customer's doorstep even in far-flung areas (Saiyed, 2011).

\subsection{Water Purifier: Tata Swach}

The "Tata Swach" is the world's cheapest household water purification system introduced by Tata Chemicals Ltd. (TCL) in December 2009 (Tiwari and Herstatt, 2012a). The objective has 
been "to reduce the incidence of water borne diseases by making safe drinking water accessible to all" (TCL, 2010: 9). Co-developed by TCL's Innovation Centre in Pune (India) it is based on "natural materials and cutting edge nanotechnology" (TCL, 2010: 9) and can eliminate $90 \%$ of the contaminants and almost all of the most serious pathogens that cause serious diseases like diarrhoea, cholera or typhoid (Ahlstrom, 2010, Singh et al., 2011).

The Swach is targeted at households, predominantly poor and/or located in rural or semiurban areas with poor access to electricity or running water. With a price tag of Rs. 999 (approx. \$20) Tata Swach became the world's most inexpensive water purifier enabling 50\% saving against its nearest competitor. It is also the world's "lowest cost" purifier, providing safe drinking water at Re. 0.10 per litre (TCL, 2010), which amounts to approx $\$ 0.002$ ( $\$ 1=I N R$ 50). As of April 2012, TCL had already sold 3 million units of Tata Swach, as per the information provided on the product website (TCL, 2012), and it hopes to sell 5 million units within next 3 years. A market for low-cost water purifier seems to exist worldwide as about 894 million people worldwide lack access to clean water and close to $90 \%$ of all deaths from diarrhoea are due to lack of sanitation and water-borne diseases (Independent, 2010). In India alone currently about 1,000 children die every day due to unsafe drinking water (Independent, 2010), which indicates towards the need for such a product. Early analysis by TCL showed that the product was principally purchased by hitherto non-consumers and confirmed that the new and affordable price point for water purifiers had succeeded in creating a new market (TCL, 2010). Around 35\% of the sales reportedly take place in rural area (Maiti, 2012).

Tata Swach was reportedly designed by Design Directions, an external company (Bhosale, 2010). The R\&D involved, apart from TCL, two more Tata group companies: namely the Tata Research Development and Design Centre (TRDDC), a division of Tata Consultancy Services (TCS), and Titan Industries (Economic Times, 2009, Economist, 2011). TRDDC, in turn, maintains academic alliances with leading universities in India and the USA, such as the Columbia University on novel nanoparticle systems for coatings, composites, and extraction/release of molecules. Further partners include the Indian Institutes of Technology in Kanpur and Mumbai, Georgia Institute of Technology, the Stanford University and University of Massachusetts (TRDDC, 2012). TCL also has manufacturing facilities in the UK, the USA and Kenya with local networks. There are reports of some non-governmental organizations distributing Tata Swach amongst the poor and the needy (Tata Group, 2011).

\subsection{Solar-powered ATMs: Vortex}

Vortex Engineering Private Limited is a company headquartered in Chennai (India). It was set-up in 2001 as an incubation project of the Indian Institute of Technology Madras (IIT-M) (Leena, 2011). The company develops and manufactures Automated Teller Machines (ATMs) that are "highly reliable, rugged, easy to use and eco-friendly" (Vortex, 2012). The solutions are specially designed to suit conditions prevalent in rural and semi-urban areas, e.g. unreliable power supply and higher illiteracy levels of end users. Vortex ATMs have an inbuilt fingerprint identification system so that the user does not need to key in a personal identification number, a feature that has apparently proved very popular in rural areas. It is estimated that, in the long-run, India alone would require at least half a million such ATMs to serve its vast hinterland consisting of about 640,000 villages, where about $70 \%$ of India's population lives. 
Vortex's ATMs can be run by solar energy and one such ATM consumes only about $10 \%$ of the total energy requirement of a conventional ATM (Vortex, 2012). The rugged ATMs of Vortex do not require air conditioning and are able to cope with temperatures ranging between $0^{\circ} \mathrm{C}$ and $50^{\circ} \mathrm{C}$, resulting in a reduction in $\mathrm{CO} 2$ emissions by at least $18,500 \mathrm{~kg}$. per annum (IBEF, n.d.). The ATMs "bring down monthly electricity bills to less than Rs. 600" (approx. \$12) (Vortex, 2012). The total cost of ownership for Vortex machines works out to be $50 \%$ less than for conventional ATMs (Mittal, 2012; Simhan, n.d.). Whilst conventional ATMs generally require fresh and crisp notes to function without hassles, Vortex's ATMs are reportedly the only ones able to dispense soiled notes, which is a critical requirement in remote areas owing to limited supply of fresh notes (IBEF, n.d.). Collaboration with IIT-M has played a key role in developing different technologies that have enabled this solution (IBEF, n.d.).

Since 2007 Vortex has installed 500 "low-cost, low-maintenance" ATMs, of them 300 solarpowered (cf. Leena, 2011). It is now linking up with local banks in India with an ambitious United Nations backed proposal to install 10,000 solar-powered ATMs by 2015 (UNDP, 2011). Tata Capital Innovations Fund and some other private sector investors have acquired a minority stake in Vortex by infusing a total sum of Rs. 500 million (approx. \$10 million). International Finance Corp. (IFC), belonging to the World Bank group, has also announced plans to invest $\$ 3$ million (Leena, 2011, Vortex, 2011). In December 2011, it signed an agreement with South Africa's WIZZIT Bank as part of a United Nations programme to provide banking services to "30 million low-income people in India and South Africa by 2015" (UNDP, 2011).

\subsection{Summary of Case Studies}

Having described six examples of successful frugal innovations from India regarding their intended "welfare effect" and the "collaborative effort", we first summarize the case-specific extent and scope of collaboration in the various phases of the innovation process in Table 2. In a next step the collaboration phase will be correlated to OGINs.

\begin{tabular}{|c|c|c|c|}
\hline Case & $\begin{array}{c}\text { Phase I } \\
\text { Conception }\end{array}$ & $\begin{array}{c}\text { Phase II } \\
\text { Implementation }\end{array}$ & $\begin{array}{c}\text { Phase III } \\
\text { Commercialization }\end{array}$ \\
\hline (A) & (B) & (C) & (D) \\
\hline $\begin{array}{l}\text { Case I } \\
\text { Tata Nano }\end{array}$ & $\begin{array}{l}\text { More than } 600 \text { auto- } \\
\text { component suppliers in the } \\
\text { idea generation process to } \\
\text { evolve target specifications } \\
\text { Inclusion of two-wheeler } \\
\text { component suppliers to } \\
\text { identify and utilize } \\
\text { analogies/synergies }\end{array}$ & $\begin{array}{l}\text { Italy's Institute of } \\
\text { Development in Automotive } \\
\text { Engineering provided final } \\
\text { refinement to the design } \\
>50 \% \text { components were } \\
\text { included as proprietary } \\
\text { parts designed by suppliers } \\
\text { on their own } \\
\text { Domestic and global } \\
\text { suppliers such as Bosch, } \\
\text { Continental, Denso, Tata } \\
\text { Johnson Controls } \\
\text { Automotive, Sona Group } \\
\text { chipped in with radical } \\
\text { innovations from their own } \\
\text { organizations }\end{array}$ & $\begin{array}{l}\text { Co-locating important } \\
\text { suppliers in the plant } \\
\text { vicinity to reduce } \\
\text { inventory and logistics } \\
\text { costs }\end{array}$ \\
\hline
\end{tabular}


An edited and peer-reviewed version of this paper has been published as:

Tiwari, R. / C. Herstatt (2012): “Frugal Innovation: A Global Networks' Perspective”, in: Die Unternehmung, 66(3): 245-274.

\begin{tabular}{|c|c|c|c|}
\hline $\begin{array}{l}\text { Case II } \\
\text { Tata Ace }\end{array}$ & $\begin{array}{l}\text { Participation of more than } \\
4,000 \text { potential customers in } \\
\text { a process to better } \\
\text { understand and } \\
\text { conceptualize the } \\
\text { requirements for a } \\
\text { disruptive product }\end{array}$ & $\begin{array}{l}\text { Outsourcing of } 81.5 \% \\
\text { content to } 120 \text { suppliers } \\
\text { with special training for the } \\
\text { design and production } \\
\text { requirements of TML } \\
\text { Gas injection technology } \\
\text { was procured from } \\
\text { Alternative Fuel Systems Inc. } \\
\text { (AFS) of Canada }\end{array}$ & $\begin{array}{l}\text { Creation of emotionally } \\
\text { appealing marketing } \\
\text { campaigns with the help of } \\
\text { external partner } \\
\text { Rediffusion } D Y \& R \\
\text { Setting-up of } 300 \text { new } \\
\text { "lean" distribution points } \\
\text { singularly focused on sales } \\
\text { Extending the network of } \\
\text { stakeholders by free } \\
\text { training for (self- } \\
\text { employed) mechanics in } \\
\text { rural areas }\end{array}$ \\
\hline $\begin{array}{l}\text { Case III } \\
\text { Electronic Voting } \\
\text { Machine (EVM) }\end{array}$ & $\begin{array}{l}\text { Election Commission of India } \\
(\mathrm{ECI}) \text { as initiator of the idea }\end{array}$ & $\begin{array}{l}\text { Prototype development in } \\
\text { collaboration of } \mathrm{ECl} \text { with } \\
\text { Electronics Corporation of } \\
\text { India Ltd. (ECIL) } \\
\text { Joint Product development } \\
\text { by ECIL and Bharat } \\
\text { Electronics } L t d \text {. (BEL) }\end{array}$ & $\begin{array}{l}\text { Government of India, and } \\
\text { especially } \mathrm{ECl} \text {, actively } \\
\text { promoting usage of EVMs } \\
\text { in other friendly countries } \\
\text { as a democracy- } \\
\text { strengthening measure }\end{array}$ \\
\hline $\begin{array}{l}\text { Case IV } \\
\text { ChotuKool }\end{array}$ & $\begin{array}{l}\text { Idea development in } \\
\text { collaboration with Innosight, } \\
\text { an innovation consulting } \\
\text { firm co-founded by Prof. } \\
\text { Clayton M. Christensen (a } \\
\text { renowned proponent of } \\
\text { "disruptive innovations") } \\
\text { Ethnographic research in } \\
\text { rural households }\end{array}$ & $\begin{array}{l}\text { Employs "thermoelectric } \\
\text { cooling", a technique } \\
\text { discovered by Jean-Charles } \\
\text { Peltier, a French national, in } \\
\text { the first part of the } 19^{\text {th }} \\
\text { century } \\
\text { (a new application for an old } \\
\text { technology) }\end{array}$ & $\begin{array}{l}\text { Distributed by villagers and } \\
\text { social entrepreneurs to } \\
\text { extend the network of } \\
\text { stakeholder (and enable a } \\
\text { new channel of earning in } \\
\text { rural and semi-urban } \\
\text { areas) } \\
\text { Distribution in } \\
\text { collaboration with the } \\
\text { Indian Postal Dept. }\end{array}$ \\
\hline $\begin{array}{l}\text { Case V } \\
\text { Tata Swach }\end{array}$ & $\begin{array}{l}\text { Idea generation in } \\
\text { collaboration with Tata } \\
\text { Research Development and } \\
\text { Design Centre (TRDDC) and } \\
\text { Titan Industries }\end{array}$ & $\begin{array}{l}\text { Designed by an external } \\
\text { partner, Design Directions } \\
\text { Developed in collaboration } \\
\text { with two other } \\
\text { (independent) Tata Group } \\
\text { companies, TCS and Titan } \\
\text { Industries }\end{array}$ & $\begin{array}{l}\text { Possibility of online } \\
\text { purchase for delivery } \\
\text { within India } \\
\text { Access to a vast retail } \\
\text { network of various Tata } \\
\text { Group companies } \\
\text { Support by NGOs engaged } \\
\text { in social welfare activities } \\
\text { that distribute water filters } \\
\text { free of cost to the needy }\end{array}$ \\
\hline $\begin{array}{l}\text { Case VI } \\
\text { Vortex ATMs }\end{array}$ & $\begin{array}{l}\text { Incubation project of the } \\
\text { Indian Institute of } \\
\text { Technology Madras (IIT-M) }\end{array}$ & $\begin{array}{l}\text { Collaboration with IIT-M to } \\
\text { develop technologies that } \\
\text { can handle spoiled currency } \\
\text { notes }\end{array}$ & $\begin{array}{l}\text { Financing by Tata Capital } \\
\text { Innovations Fund and the } \\
\text { World Bank group } \\
\text { Collaboration with South } \\
\text { Africa's WIZZIT Bank }\end{array}$ \\
\hline
\end{tabular}


Table 2: A summary of the role of OGINs in the selected instances of frugal innovation

These case-specific insights are now transferred to Table 3, which shows the extent of inhouse and collaborative development in domestic and overseas markets and the phase of the innovation process so that generalizations can be made.

As evident from Table 3, the extent of the involvement of OGINs in product development for frugal innovations seems to be substantial. Even though the cases were selected for having at least some elements of collaboration, but the extent of actual collaboration, as measured by involvement of external partners in the various phases of the innovation process is quite significant. The highest degree of development activity was concentrated in the home base. The firm-internal R\&D capacities based at the home base and the domestic collaborative partners (domestic-owned as well as affiliates of MNCs) were the most important source of ideas, implementation and commercialization, which probably signifies the need for local capabilities in such a market. The most dominant forms of product development were "Domestic In-house Development" (column B) and "Domestic Collaborative Development" (column D). It must be noted that in case of DCD the partners can be and often are affiliates of MNCs. For example, Indian subsidiaries of the German automotive major Bosch have played a key role in the conception and implementation of the Tata Nano. Involvement of "Offshore Collaborative Development" in frugal innovations was identified in five of the six cases, albeit to a varying degree. Their collaboration most often seems to have been sought in the implementation phase (four times out of five instances). "Offshore In-house Development" (OID) was found to be the least spread form of OGINs in the cases discussed here. Only firms belonging to the Tata Group were found to have own in-house development capabilities in offshore locations. EVMs are the only product in the study, which did not involve offshore collaboration.

\begin{tabular}{|c|c|c|c|c|}
\hline \multirow{3}{*}{$\begin{array}{c}\text { Product } \\
\text { Innovation }\end{array}$} & \multicolumn{2}{|c|}{ In-house Development } & \multicolumn{2}{|c|}{ Collaborative Development } \\
\hline & Closed-Model & Open G & al Innovation Net & ork (OGIN) \\
\hline & Domestic & Offshore & Domestic & Offshore \\
\hline (A) & (B) & (C) & (D) & $(E)$ \\
\hline $\begin{array}{l}\text { Case I } \\
\text { Tata Nano }\end{array}$ & $\begin{array}{l}\text { Conception } \\
\text { Implementation } \\
\text { Commercialization }\end{array}$ & $\begin{array}{l}\text { Conception } \\
\text { Implementation }\end{array}$ & $\begin{array}{l}\text { Conception } \\
\text { Implementation } \\
\text { Commercialization }\end{array}$ & Implementation \\
\hline $\begin{array}{l}\text { Case II } \\
\text { Tata Ace }\end{array}$ & $\begin{array}{l}\text { Conception } \\
\text { Implementation } \\
\text { Commercialization }\end{array}$ & & $\begin{array}{l}\text { Conception } \\
\text { Implementation } \\
\text { Commercialization }\end{array}$ & $\begin{array}{l}\text { Implementation } \\
\text { Commercialization }\end{array}$ \\
\hline $\begin{array}{l}\text { Case III } \\
\text { Electronic Voting } \\
\text { Machine (EVM) }\end{array}$ & $\begin{array}{l}\text { Conception } \\
\text { Implementation } \\
\text { Commercialization }\end{array}$ & & $\begin{array}{l}\text { Conception } \\
\text { Implementation } \\
\text { Commercialization }\end{array}$ & \\
\hline $\begin{array}{l}\text { Case IV } \\
\text { ChotuKool }\end{array}$ & $\begin{array}{l}\text { Conception } \\
\text { Implementation } \\
\text { Commercialization }\end{array}$ & & $\begin{array}{l}\text { Conception } \\
\text { Implementation } \\
\text { Commercialization }\end{array}$ & $\begin{array}{l}\text { Conception } \\
\text { Implementation }\end{array}$ \\
\hline $\begin{array}{l}\text { Case V } \\
\text { Tata Swach }\end{array}$ & $\begin{array}{l}\text { Conception } \\
\text { Implementation } \\
\text { Commercialization }\end{array}$ & $\begin{array}{l}\text { Conception } \\
\text { Implementation }\end{array}$ & $\begin{array}{l}\text { Conception } \\
\text { Implementation } \\
\text { Commercialization }\end{array}$ & $\begin{array}{l}\text { Conception } \\
\text { Implementation }\end{array}$ \\
\hline $\begin{array}{l}\text { Case VI } \\
\text { Vortex ATMs }\end{array}$ & $\begin{array}{l}\text { Conception } \\
\text { Implementation } \\
\text { Commercialization }\end{array}$ & & $\begin{array}{l}\text { Conception } \\
\text { Implementation } \\
\text { Commercialization }\end{array}$ & Commercialization \\
\hline
\end{tabular}




\section{Discussion \& Implications}

\subsection{Examinations of Propositions}

In this section we examine the evidence provided by the cases in regard to the three propositions developed in sections 2 and 3.

\section{Role of the Value Proposition}

The cases described above seem to support the first proposition that frugal innovations have a greater chance of commercial success if their value proposition can fulfill the twin objectives of reducing the cost of ownership, as suggested in (Tiwari and Herstatt, 2012a) while matching customer aspirations in terms of image and quality (Subrahmanyan and Gomez-Arias, 2008, Prahalad and Mashelkar, 2010). The involvement of various collaboration partners was found to have been substantial in all phases of the innovation process and seems to have helped considerably to reduce the cost of ownership for the endconsumer, which is in accordance with other studies of supplier-integration in the process of product development (Kersten and Kern, 2003). This strengthened the welfare effect (affordability of product which contributes to raise the basic standard of living). The example of the Tata Nano illustrates this point very well. The involvement of well-established and renowned component suppliers such as Bosch with its long treasure of German automotive engineering could help Tata not only in terms of actual good quality for the vehicle but also in terms of the perceived quality. Bosch, in turn, hoped to learn valuable lessons in frugal engineering and simultaneously pursued the strategic intention of occupying a market position which could have otherwise been taken by a (domestic) competitor and then used as a launch platform in more established markets such as Germany (Palepu et al., 2011). This also illustrates the point that collaboration can help the OGIN partners to utilize mutual synergies. Even the initial setback suffered by the Tata Nano also underscores this reasoning. The early setback was caused by the customer perception of quality shortcomings and the stigma of driving a "cheap" vehicle. With transparent investigations, including an independent international forensic expert, TML could soon quell away the doubts. The Tatas, however, also had to learn a valuable marketing lesson that it should have been rather the innovative aspects and the international-standard quality which should have been highlighted rather than the mere cost savings.

\section{Importance of OGINs for Frugal Innovations}

The second proposition that companies can increase the probability of offering the right value proposition, if they are able to successfully integrate their product development process in open global innovation networks, is also supported by the cases. Emphasis was put (across all cases) on use of combining existing technologies (Kodama, 1992, Kalogerakis et al., 2010) as far as possible to sidestep avoidable costs and keep the question of affordability in focus. All the examples discussed above have resulted from collaborative development in OGINs cutting across firm and, in some instances, national boundaries. Involving established, external expertise does not only help get access to know-how but also enhances the quality perception and the image effect. Already highlighted by the example of the Tata Nano, this point is further reinforced by the collaborative development of Vortex' 
ATMs. The involvement of the renowned Indian Institute of Technology Madras (IIT-M) acts as a reassurance to potential customers in banks, which traditionally act in a very conservative manner regarding introduction of new technology due to high safety concerns. The involvement of two reputed public sector enterprises and the Election Commission of India has surely had a reassuring effect on many potential voters and political activists. The cases also seem to support the connect between OGINs and their contribution to the reduction of market and technology uncertainty that resulted from the collaborative effort (Kersten and Kern, 2003, Kersten et al., 2006). The increasing role of OGINs, especially in the international context, is also supported by hard data. Between August 1991 and August 2010, the Government of India approved more than 8,000 agreements of inwards foreign technology collaborations (GOI, 2011). Figure 4 shows India's payments and receipts of royalties and fees for licenses and copyrights with its international partners. As evident from the chart, India is increasingly making use of global know-how and intellectual properties.

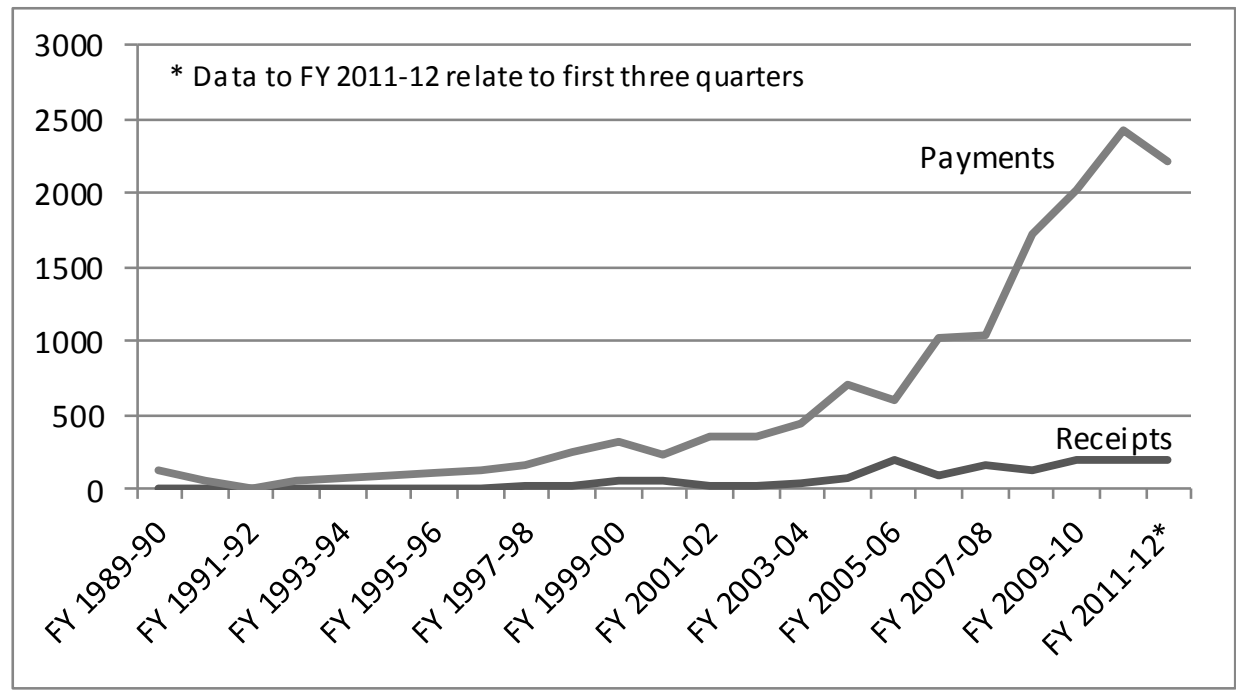

Figure 4: Payment and receipts of royalty, license and copyright fees by India (in million USD) ${ }^{9}$

\section{Engagement in Lead Markets}

A lead market ideally has a large number of consumers, whose socio-economic and/or geographic conditions are comparable to many others in different parts of the world (Beise, $2001,107)$. The resultant economies of scale help lower the costs and enhance the welfare effect of frugal innovations. In all cases of product innovations discussed above, India as a lead market for frugal innovations provided the innovating firms with substantial economies of scale.

Simultaneously the deep integration of domestic-based collaborative partners (whether domestically-owned or affiliates of MNCs) in the innovation process of frugal innovators supported the proposition that setting up innovation capabilities in product-specific lead markets can increase the probability to identify and access suitable OGINs. Also the data on foreign technology collaborations as well on royalty payments \& receipts also indicate that India is increasingly in a position to enable access to OGINs. Apart from foreign technology

9 Source: Authors' calculations based on various publications by Reserve Bank of India. Data for FY 2011-12 relate to first three quarters. 
collaborations (FTCS) there has been a significant inward flow of FDI to India for establishing local R\&D capabilities (TIFAC, 2006, Herstatt et al., 2008, OECD, 2008a). Even though there are no reliable data available on the amount of FDI, whose primary purpose was to conduct R\&D in India, Reserve Bank of India undertakes a representative analysis of audited annual accounts filed by a sample of selected FDI firms, whereby the sample size and participants keep changing. Table 4 shows annual expenditure by these selected firms on R\&D in India. 


\begin{tabular}{|c|c|c|c|c|}
\hline \multirow{2}{*}{ Fiscal Year } & \multicolumn{2}{|c|}{ R\&D Expenditure } & \multirow{2}{*}{ Sample Size } & $\begin{array}{c}\text { Average } \\
\text { Expenditure } \\
\text { (million USD) }\end{array}$ \\
\cline { 2 - 3 } & Rs. (million) & USD (million) & & 0.11 \\
\hline $2000-01$ & 2,266 & 49.6 & 465 & 0.10 \\
\hline $2001-02$ & 2,449 & 51.3 & 465 & 0.12 \\
\hline $2002-03$ & 2,987 & 61.7 & 490 & 0.16 \\
\hline $2003-04$ & 3,710 & 80.7 & 508 & 0.28 \\
\hline $2004-05$ & 6,570 & 146.2 & 501 & 0.31 \\
\hline $2005-06$ & 7,140 & 161.3 & 524 & 0.69 \\
\hline $2006-07$ & 16,690 & 368.6 & 533 & 0.81 \\
\hline $2007-08$ & 22,230 & 552.4 & 681 & 0.83 \\
\hline $2008-09$ & 26,010 & 566.5 & 681 & 0.88 \\
\hline $2009-10$ & 28,330 & 597.5 & 681 & \\
\hline
\end{tabular}

Since the sample is not exhaustive, the actual amount of expenditure can be reasonably assumed to be higher than the $\$ 597.5$ million in FY 2009-10. Notwithstanding this statistical incompleteness the R\&D expenditure has grown by about 12 times within past 10 years. Average expenditure pro company has also grown from $\$ 0.11$ million in FY 2000-01 to $\$ 0.88$ million in FY 2009-10.

Domestic R\&D expenditures in India too have risen considerably in the previous years. While India spent a total of Rs. 161.99 billion (\$3.6 billion) on R\&D in FY 2000-01, this figure had grown nearly 3-fold to an estimated Rs. 377.78 billion (\$9.4 billion) by FY 2007-08, the latest year for which official data are available (GOI, 2009). ${ }^{11}$ At year-end 2010 there were 544 universities (or comparable institutions) as well as 31,324 colleges with faculty strength of nearly 700,000. More than 14.6 million students were enrolled at institutions of higher education (GOI, 2011). Thus, India seems to possess several advantages in respect of innovation networks, which can be cultivated by firms. It must be noted however that the quality of education varies considerably across institutions and industry-academia collaboration is not well entrenched in all institutions (Herstatt et al., 2008), so that a careful selection and proactive cultivation may be imperative.

India has also emerged as a key source of outward FDI and many Indian multinationals have established presence abroad, including in the developed countries, both by means of brownfield and greenfield investments (Sauvant et al., 2010). These investments have led to creation of overseas R\&D capabilities and collaborations thus creating positive spill-over effects for India's national innovation system.

${ }^{10}$ Source: Author's calculations based on RBI data on "Finances of Foreign Direct Investment Firms" from multiples studies published during 2003 and 2011. Values have been converted from Indian Rupees into USD using official average exchange rates for the respective fiscal years (RBI, 2011). Since sample sizes across the surveys vary the data are not comparable across the whole time series.

${ }^{11}$ Values have been converted from Indian Rs. into USD by the authors using official average exchange rates for the respective fiscal years (RBI, 2011). 


\subsection{Research Implications \& Limitations}

The case studies entail some potentially crucial implications for firms that intend to serve markets for frugal products. First, serving price-sensitive customers in developing or developed markets is not feasible by stripping down the existing products to a bare minimum in order to reduce costs/price. Customer perception of cheap quality can create a major hurdle in product success. It is important to match the customer aspirations in terms of aesthetics, quality and perceived brand.

Second, affordable price is a necessary but insufficient condition. The study discovered that it is the overall value proposition of a product, which is the key to success. It is not the cheapest product, which is likely to succeed. Rather, a product that offers a quality level at least comparable to the standard entry-level products, combined with a positive social image and available for an attractive cost of ownership across its whole life span.

Third, companies need to work with a "clean slate" approach while devising frugal innovations. Functionalities and technologies should not be incorporated purely on account of their legacy value (Arthur, 2000). The case studies showed that the absence of any legacy system created clarity about features that were necessary, nice to have, and not needed. This however does not mean that firms should discard existing technologies. On the contrary, once the product features are identified, a proactive attempt should be made to identify existing technologies/analogies that can fulfil the requirements so that costs of developments can be reduced while market and technology uncertainties can be avoided to the greatest extent possible. To achieve this objective, firms should look beyond the traditional boundaries of firms, industries and nations. The "not-invented-here-syndrome" is not compatible with the idea of frugal innovations.

Fourth, identifying suitable product-specific lead markets and locating at least parts of the innovation value chain there may enable a crucial competitive advantage to achieve this goal. On this score, India can have a signalling function for potential customers in many regions of the world, where the level of economic development is comparable or even lagging behind India's. Technologies that are able to function under given infrastructural deficits in India should normally be able to cope with similar challenges in other developing economies of Asia, Africa or Latin America. Of course, product-specific lead markets can also emerge in countries other than India.

Fifth, developing (affordability-driven) frugal innovations seems to require a high degree of embeddedness in the social context of the potential consumers to understand their needs, wishes, mind-set, cultural preferences, and not the least, infrastructural shortcomings. Offshore development without substantial local development capacities is not expected to function well. As Table 3 intriguingly reveals, in all cases, the most extensive work (related to conception and implementation) was located in the domestic settings, even though it involved both domestic partners and affiliates of MNCs. At the same time the level of contribution from firms' own in-house offshore subsidiaries, or also from other offshore partners, was somewhat limited and rather focused on technical implementation and/or commercialization. The most important impulses regarding conceptualization seem to have been generated in the embedded social context of the lead market for frugal innovations. 
Finally, it is expected that the increasing environmental concerns, scarcity of resources, and the continuing financial distress in some developed economies would increase demand for frugal innovations also in price-sensitive and/or environment-conscious consumer groups in the industrialized economies (Gibbert et al., 2007, Cappelli et al., 2010, Economist, 2010, Kus et al., 2011, Economist, 2012, Sharma and lyer, 2012). Early experiences with frugal innovations could help firms prepare for a (probably prolonged) period of austerity.

Since the research is of an exploratory/indicative nature based on a small sample of case studies, it would be useful to conduct more in-depth case studies to generate insights into mechanisms of collaboration spanning across the whole innovation value chain. A need for more academic/theory-building research is also found to be caused by an increasingly complex and globalized world. The traditional classifications of firm and national boundaries are becoming obsolete as firms invest abroad and have associates and affiliates in many parts of the world. Existing categorizations may be creating a "blind spot" that make it difficult identify real life instances of open innovations.

\section{Conclusions}

Our research indicates that while the paradigm of creating "low cost" innovations to tap new sources of revenue continues to hold true, there is need for a substantial re-alignment. Purely cost driven innovations targeted at "the poorest of the poor" seem to have so far failed to fulfil the very high expectations imposed in them. While the social stigma attached to purely functional and "cheap" products has created (in some instances, an imaginary) perception of flawed quality in the minds of those very consumers that are supposed to be the intended beneficiary, many firms have been struggling to offer quality products at sustainable price points owing to the consumers' lack of real purchasing power (at market exchange rates) in fragmented markets.

The analysis of six relatively successful affordability-driven product innovations ("frugal innovations") from various firms and industries indicates that firms can increase the probability of commercial success if they adopt the process of collaborative development in open global innovation networks. Such networks enable access to new and existing technologies, combine new ideas and by joining forces firms may be able to master the challenges of a fragmented customer base. A possible solution lies in creating products that are not necessarily targeted at "the poor" but rather at price-sensitive customers, that by choice or otherwise, purchase products that reduce the cost of ownership while matching the aspirations for individual and family welfare, economic progress and social recognition. There is a need for reversing the mind-set that feels more at ease at creating high-end products and then to strip them down for the poor. Rather, we need a new way of thinking that creates attractive, good-enough products that can be offered in basic versions and "stripped up" to match individual wishes of the customer depending on his willingness to spend. OGINs with their know-how, resources and market access to different customer segments can act as key enablers in implementing this paradigm shift. 


\section{References}

Ahlstrom, D. (2010), "Innovation and Growth: How Business Contributes to Society", Academy of Management Perspectives, Vol. 24, No. 3, pp. 11-24.

Anthony, S. D. (2012), The Little Black Book of Innovation: How It Works, How to Do It, Harvard Business Review Press, Boston, MA.

Arthur, W. B. (ed.) (2000), Increasing Returns and Path Dependence in the Economy, Ann Arbor: University of Michigan Press.

Bartlett, C. A. \& Ghoshal, S. (1990), "Managing innovation in the transnational corporation", in Bartlett, C. A., Doz, Y. L. \& Hedlund, G. (eds.), Managing the Global Firm, Routledge, London, pp. 215-255.

Beise, M. (2001), Lead Markets: Country-Specific Success Factors of the Global Diffusion of Innovations, Physica-Verlag, Heidelberg.

Beise, M. (2004), "Lead Markets: Country-Specific Success Factors of the Global Diffusion of Innovations", Research Policy, Vol. 33, No. 6-7, pp. 997-1018.

Bellman, E., Misquitta, S. \& Glader, P. (2009), "Indian Firms Shift Focus to the Poor", Wall Street Journal, p.A14, 21.10.2009.

Bhosale, J. (2010), "India is now a potential design pool", Economic Times, 28.04.2010.

Buse, S., Tiwari, R. \& Herstatt, C. (2010), "Global Innovation: An Answer to Mitigate Barriers to Innovation in Small and Medium-sized Enterprises", International Journal of Innovation and Technology Management, Vol. 7, No. 3, pp. 215-227.

Cappelli, P., Singh, H., Singh, J., et al. (2010), "The India Way: Lessons for the U.S.", Academy of Management Perspectives, Vol. 24, No. 2, pp. 6-24.

Chacko, P., Noronha, C. \& Agrawal, S. (2010), Small Wonder: The Making of the Nano, Westland Ltd., Chennai.

Chakravarthy, B. \& Coughlan, S. (2011), "Emerging market strategy: innovating both products and delivery systems", Strategy \& Leadership, Vol. 40, No. 1, pp. 27-32.

Chesbrough, H. (2003), Open Innovation: The New Imperative for Creating and Profiting from Technology, Harvard Business School Press, Boston.

Chesbrough, H. (2006), Open Business Models: How To Thrive in The New Innovation Landscape, Harvard Business School Press, Boston.

Chesbrough, H., Vanhaverbeke, W. \& West, J. (2008), Open Innovation: Researching A New Paradigm, Oxford University Press, Oxford.

Christensen, C. M. \& Raynor, M. E. (2003), The innovator's solution: creating and sustaining successful growth, Harvard Business School Press, Boston, MA.

(2012), Internationalisation of business investments in R\&D and analysis of their economic impact (Deliverable 7: Analysis Report). Project commissioned by the European Commission, DG Research \& Innovation (Contract Nr. RTD/DirC/C3/2010/S12.563818). Vienna: AIT Austrian Institute of Technology (Foresight \& Policy Development Department), and the Vienna Institute for International Economic Studies.

den Ouden, E. (2012), Innovation Design: Creating Value for People, Organizations and Society, Springer, London.

Dhume, S. (2011), "Unloved at Any Speed", available at: http://www.foreignpolicy.com/articles/2011/10/07/tata nano unloved at any spe ed?page=full (accessed 27.04.2012).

(2010), Annual Report 2009-10. Hyderabad: Electronics Corporation of India Limited.

Economic Times. (2009), "Tatas do a Nano in water purifier at Rs 1k", Economic Times, 08.12.2009. 
(2010), Scarcity and globalisation: A needier era. The Economist. London.

(2011), The Tata group: Out of India. The Economist. London.

(2012), Asian innovation: Frugal ideas are spreading from East to West. The Economist. London.

Eisenhardt, K. M. (1989), "Building Theories from Case Study Research", Academy of Management Review, Vol. 14, No. 4, pp. 532-550.

Eisenhardt, K. M. (1991), "Better Stories and Better Constructs: The Case for Rigor and Comparative Logic", Academy of Management Journal, Vol. 16, No. 3, pp. 620-627.

Eyring, M. J., Johnson, M. W. \& Nair, H. (2011), "New Business Models In Emerging Markets", Harvard Business Review, Vol. 89, No. 1/2, pp. 88-95.

(2004), Semiannual Report to Congress: October 1, 2003 - March 31, 2004. Washington D.C.: Federal Election Commission of the United States of America.

Fontanella-Khan, J. \& Munshi, N. (2011), "Tata fails to engineer success for Nano", Financial Times, 09.10.2011.

Gassmann, O., Enkel, E. \& Chesbrough, H. (2010), "The Future of Innovation", R\&DManagement, Vol. 40, No. 3, pp. 213-221.

Gerybadze, A. (1997), "Globalisierung von Forschung und wesentliche Veränderungen im F\&E-Management internationaler Konzerne", in Gerybadze, A., Meyer-Krahmer, F. \& Reger, G. (eds.), Globales Management von Forschung und Innovation, SchäfferPoeschel Verlag, Stuttgart, pp. 17-37.

Gerybadze, A. \& Reger, G. (1999), "Globalization of R\&D: recent changes in the management of innovation in transnational corporations", Research Policy, Vol. 28, No. 2-3, pp. 251-274.

Gibbert, M., Hoegl, M. \& Välikangas, L. (2007), "In Praise of Resource Constraints", MIT Sloan Management Review, Vol. 48, No. 3, pp. 15-17.

Godrej. (2012), "Product website for ChotuKool", available at: http://www.chotukool.in (accessed 25.02.2012).

GOI (2009), Research and Development Statistics 2007-08, Government of India Department of Science and Technology (NSTMIS Division), New Delhi.

(2011), Annual Report 2010-11. New Delhi: Department of School Education \& Literacy and Department of Higher Education, Ministry of Human Resource Development, Government of India.

(n.d.), A State-of-the-Art, User Friendly and Tamper Proof Electronic Voting Machine (EVM). Presentation. New Delhi: Government of India - Election Commission of India.

Govindarajan, V. \& Trimble, C. (2012), Reverse Innovation: Create Far From Home, Win Everywhere, Harvard Business Review Press, Boston.

Gupta, A. K. (2010), "Grassroot Green Innovations for Inclusive, Sustainable Development", in López-Carlos, A. (ed.) The Innovation for Development Report 2009-2010: Strengthening Innovation for the Prosperity of Nations, Palgrave Macmillan, Hampshire, pp. 137-146.

Gupta, N. S. (2008), "Designer Girish Wagh: The whizkid who shaped Tata Nano", Economic Times, 12.01.2008.

(2004), Selling to the Poor. Foreign Policy.

(2008), India's National Innovation System: Key Elements and Corporate Perspectives. Economics Series, Working Paper No. 96. Honolulu, Hawaii: East-West Center. 
Herstatt, C. \& Verworn, B. (2004), "The Fuzzy Front End of Innovation", in EITIM (ed.) Bringing Technology and Innovation into the Boardroom, Palgrave MacMillan, Houndmills, pp. 347-373.

Herstatt, C. \& von Hippel, E. (1992), "From experience: Developing new product concepts via the lead user method: A case study in a 'low-tech' field", Journal of Product Innovation Management, Vol. 9, No. 3, pp. 213-221.

Independent. (2010), "India's Tata launches low-cost water filter for rural poor", available at: http://www.independent.co.uk/life-style/health-and-families/health-news/indiastata-launches-lowcost-water-filter-for-rural-poor-1836164.html (accessed 25.02.2012).

Innosight. (2012), "About Us: Driving Transformational Growth Through Innovation Strategy", available at: http://www.innosight.com/about-us/index.cfm (accessed 25.02.2012).

Ireland, J. (2008), "Lessons for successful BOP marketing from Caracas' slums", Journal of Consumer Marketing, Vol. 25, No. 7, pp. 430-438.

Islam, F. (2010), "Socioeconomy of innovation and entrepreneurship in a cluster of SMEs in emerging economies ", Competitiveness Review, Vol. 20, No. 3, pp. 267-278.

Kalogerakis, K., Lüthje, C. \& Herstatt, C. (2010), "Developing Innovations Based on Analogies: Experience from Design and Engineering Consultants", Journal of Product Innovation Management, Vol. 27, No. 3, pp. 418-436.

Karamchandani, A., Kubzansky, M. \& Lalwani, N. (2011), "Is the Bottom Of the Pyramid Really for You", Harvard Business Review, Vol. 89, No. 3, pp. 107-111.

Karnani, A. (2007a), "Doing Well by Doing Good - Case Study: 'Fair and Lovely' Whitening Cream", Strategic Management Journal, Vol. 28, No., pp. 1351-1357.

Karnani, A. (2007b), "The Mirage of Marketing to the Bottom of the Pyramid: How the Private Sector can Help Alleviate Poverty", California Management Review, Vol. 49, No. 4, pp. 90-111.

Karnani, A. (2009), "Romanticising the Poor Harms the Poor", Journal of International Development, Vol. 21, No., pp. 76-86.

Kersten, W. \& Kern, E.-M. (2003), "Integration von Lieferanten in den Produktentwicklungsprozess", Industrie Management, Vol. 19, No. 5, pp. 17-20.

Kersten, W., Koeppen, B., Kern, E.-M., et al. (2006), "Wertschopfungsnetzwerke intenationaler Automobilhersteller in Indien", in Wojda, F. \& Berth, A. (eds.), Innovative Kooperationsnetzwerke, Deutscher Universitats-Verlag, Wiesbaden, pp. 247-271.

Khanna, T. \& Palepu, K. G. (2010), Winning in Emerging Markets: A Road Map for Strategy and Execution, Harvard Business Press Books Boston, MA.

Kodama, F. (1992), "Technology Fusion and The New R\&D", Harvard Business Review, Vol. 70, No. 4, pp. 70-78.

(2012), MOT in Transition: From Technology Fusion to Technology-Service Convergence. Keynote Address at the 21st International Conference on Management of Technology. Hsinchu, Taiwan: IAMOT.

Kumar, A. (2009), "Godrej's Nano: Chotukool", available at: http://www.businessstandard.com/india/news/godrej/s-nano-chotukool/377275/ (accessed 25.02.2012).

(2011), Austerity Measures Impact Design. 18th International Product Development Management Conference. Delft, The Netherlands. 
Leena, S. B. (2011), "Tata Capital, Aavishkaar acquiring minority stakes in Vortex", Live Mint, 14.12.2011.

London, T. (2009), "Making Better Investments at the Base of the Pyramid", Harvard Business Review, Vol. 87, No. 5, pp. 106-113.

London, T. \& Hart, S. L. (2004), "Reinventing strategies for emerging markets: beyond the transnational model", Journal of International Business Studies, Vol. 35, No. 5, pp. 350-370.

London, T. \& Hart, S. L. (eds.) (2010), Next Generation Business Strategies for the Base of the Pyramid: New Approaches for Building Mutual Value, Upper Saddle River, New Jersey: FT Press.

Lüthje, C. \& Herstatt, C. (2004), "The Lead User method: an outline of empirical findings and issues for future research", R\&D Management, Vol. 34, No. 5, pp. 553-568.

Mahajan, V. (2009), Africa Rising: How 900 million African consumers offer more than you think, Wharton School Publ., Upper Saddle River, NJ.

Mahajan, V., Banga, K. \& Gunther, R. (2006), The 86 Percent Solution: How to Succeed in the Biggest Market Opportunity of the Next 50 Years, Wharton School Publishing, Upper Saddle River, New Jersey.

Mahalakshmi, B. V. (2011), "GE Healthcare puts $\$ 50 \mathrm{~m}$ into low-cost launches in 3 years", available at: http://www.financialexpress.com/news/ge-healthcare-puts-50-m-intolowcost-launches-in-3-years/885625/ (accessed 25.02.2011).

Maiti, M. (2012), "Tata's nano purifier big hit with India, falters in Bharat", Financial Chronicle, 28.01.2012, 28.01.2012.

Malhotra, J. (2009), "Questions and Answers: Prof. Anil Kumar Gupta", Wall Street Journal, 24.09.2009.

(2012), Tata Motors' R\&D Focus. Forbes India. Mumbai ed.

Mohile, S. S. (2012), "First-time buyers, women give Nano a push", Live Mint, 23.04.2012.

OECD (2002), Frascati Manual: Proposed Standard Practice for Surveys on Research and Experimental Development, Organisation for Economic Co-Operation and Development, Paris.

OECD (2005), Oslo Manual: Guidelines for Collecting and Interpreting Innovation Data, Organisation for Economic Co-Operation and Development (in joint publication with Eurostat), Paris.

OECD (2008a), Internationalisation of Business R\&D: Evidence, Impacts and Implications, Organisation for Economic Co-Operation and Development, Paris.

OECD (2008b), Open Innovation in Global Networks, Organisation for Economic Co-Operation and Development, Paris.

(2011), Tata Nano - The People's Car. Case 9-710-420. Boston, MA: Harvard Business School. (2008), Tata Motors: The Tata Ace. Case 9-108-011. Boston, MA: Harvard Business School.

Porter, M. E. (1990), The Competitive Advantage of Nations, Free Press, New York.

Prahalad, C. K. (2005), The Fortune at the Bottom of the Pyramid: Eradicating Poverty through Profits, Wharton School Publishing, Upper Saddle River, NJ.

(2002), The Fortune at the Bottom of the Pyramid. Strategy + Business.

Prahalad, C. K. \& Mashelkar, R. A. (2010), "Innovation's Holy Grail", Harvard Business Review, Vol. 88, No. 7/8, pp. 132-141.

Radjou, N., Prabhu, J. \& Ahuja, S. (2012), Jugaad Innovation: Think Frugal, Be Flexible, Generate Breakthrough Growth, Jossey-Bass, San Francisco. 
Ram, S. \& Sheth, J. N. (1989), "Consumer Resistance to Innovations: The Marketing Problem and its Solutions", Journal of Consumer Marketing, Vol. 6, No. 2, pp. 5-14.

(2010), On the Delivery of Pro-Poor Innovations: Managerial Lessons from Sanitation Activists in India. Working Paper No. 2010-018. Maastricht: United Nations University - Maastricht Economic and social Research and training centre on Innovation and Technology (UNU-MERIT).

(2011), Handbook of Statistics on the Indian Economy. Mumbai: Reserve Bank of India.

Sachwald, F. (2008), "Location choices within global innovation networks: the case of Europe", Journal of Technology Transfer, Vol. 33, No. 4, pp. 364-378.

Saiyed, K. (2011), "Thanks to postmen, 'ChotuKool' is a rage in rural households", available at: http://www.indianexpress.com/news/thanks-to-postmen-chotukool-is-a-rage-inrural-households/890324/0 (accessed 25.02.2012).

Sauvant, K. P., Pradhan, J. P., Chatterjee, A., et al. (eds.) (2010), The Rise of Indian Multinationals: Perspectives on Indian Outward Foreign Direct Investment

New York: Palgrave Macmillan.

Schuh, G., Lenders, M. \& Hieber, S. (2011), "Lean Innovation - Introducing Value Systems to Product Development", International Journal of Innovation and Technology Management, Vol. 8, No. 1, pp. 41-54.

Schuster, T. \& Holtbrügge, D. (2011), "Tata Nano: The Car for the Bottom-of-the-Pyramid", in Zentes, J., Swoboda, B. \& Morschnett, D. (eds.), Fallstudien zum Internationalen Management: Grundlagen - Praxiserfahrungen - Perspektiven, 4. Auflage ed, Gabler, Wiesbaden, pp. 83-102.

Sehested, C. \& Sonnenberg, H. (2008), Lean Innovation: A Fast Path from Knowledge to Value, Springer, Heidelberg.

(2010), The Importance of Frugal Engineering. Strategy + Business.

Sharma, A. \& Iyer, G. R. (2012), "Resource-constrained product development: Implications for green marketing and green supply chains", Industrial Marketing Management, Vol. forthcoming, No.

(2012), Statistical Profile of Automobile Industry in India 2010-2011. New Delhi: Society of Indian Automobile Manufacturers.

Singh, M. G., Gambhir, A. \& Dasgupta, J. (2011), "Innovation in India: Affordable Innovations", in Dutta, S. (ed.) The Global Innovation Index 2011: Accelerating Growth and Development, INSEAD, Fontainebleau, pp. 77-86.

Singh, S. K. \& Chaudhuri, A. (2009), "The reality of India: folding constraints into business strategy", Journal of Business Strategy, Vol. 30, No. 4, pp. 5-16.

Subrahmanyan, S. \& Gomez-Arias, J. T. (2008), "Integrated approach to understanding consumer behavior at bottom of pyramid", Journal of Consumer Marketing, Vol. 25, No. 7, pp. 402-412.

(2011), Tata Chemicals distributes Tata Swach purifiers in villages and schools of Babrala, Uttar Pradesh. Press Release, 30.01.2011. Mumbai.

(2010), 71st Annual Report 2009-10. Mumbai: Tata Chemicals Ltd.

TCL. (2012), "Tata Swach 30 Lakh Celebrations Offer", available at: http://www.tataswach.com/termsandcondition.aspx (accessed 30.04.2012).

Thakkar, M. (2010), "Tata Motors to take Nano on a 12,000-km test drive", The Economic Times, 27.05.2010.

TIFAC (2006), FDI in the R\&D Sector: Study for the Pattern in 1998-2003, Technology Information, Forecasting and Assessment Council, New Delhi. 
Tiwari, R. \& Herstatt, C. (2012a), "Assessing India's Lead Market Potential for Cost-effective Innovations", Journal of Indian Business Research, Vol. 4, No. 2, pp. 97-115.

(2012b), India - A Lead Market for Frugal Innovations? Extending the Lead Market Theory to Emerging Economies. Working paper No. 67. Hamburg: Institute for Technology and Innovation Management, Hamburg University of Technology.

(2007), Sixty-second annual report 2006-07. Mumbai: Tata Motors Ltd.

(2010a), Sixty-fifth annual report 2009-10. Mumbai: Tata Motors Ltd.

(2010b), Tata Motors reconfirms robustness of Tata Nano design. Press Release. Mumbai: Tata Motors Ltd.

(2011), Sixty-sixth annual report 2010-2011. Mumbai: Tata Motors Ltd.

TML. (2012a), "Tata Motors European Technical Centre", available at: http://uk.tata.com/businesses/eng/inside.aspx?sectid=XVzDcPpcXGQ= $\quad$ (accessed 29.05.2012).

(2012b), Tata Motors March sales at 100,414 nos. . Press Release. Mumbai: Tata Motors Ltd. TRDDC. (2012), "Academic Alliances (of the Tata Research Development and Design Centre)", available at: www.tcs-trddc.com/trddc website/scripts/alliances.php (accessed 27.04.2012).

(2011), More than 30 million rural poor in India and South Africa to benefit from banking services. Press Release, 14.12.2011. New York: United Nations Development Programme.

(2005), Potential Offshoring of ICT-Intensive Using Occupations. Working Party on the Information Economy. Paris: Organisation for Economic Co-operation and Development.

Venn, R. \& Berg, N. (2011), "Base-of-the-Pyramid-Strategien in Emerging Markets: Interorganisationales Lernen zur Kreation von Innovationen in sektorübergreifenden Partnerschaften", Zeitschrift für Management, Vol. 6, No. 3, pp. 261-286.

Verma, A. (2005), "Policing Elections in India", India Review, Vol. 4, No. 3-4, pp. 354-376.

(2011), Vortex Engineering Raises VC Funding of Rs. 370 mn. Press Release, 17.12.2011. Chennai: Vortex Engineering Pvt. Ltd.

Vortex. (2012), "Company website", available at: http://vortexindia.co.in/ (accessed 21.02.2012).

(2009), The Next Billions: Business Strategies to Enhance Food Value Chains and Empower the Poor. Prepared in collaboration with The Boston Consulting Group. Geneva: World Economic Forum.

Whitney, P. (2010), "Reframing Design for the Base of the Pyramid", in London, T. \& Hart, S. L. (eds.), Next Generation Business Strategies for the Base of the Pyramid: New Approaches for Building Mutual Value, FT Press, Upper Saddle River, New Jersey, pp. 165-192.

Yin, R. K. (2003), Case Study Research: Design and Methods, SAGE Publications, Thousand Oaks, California. 


\section{A Brief Selection of Related Publications from Our Institute}

Tiwari, R. and C. Herstatt (2012): "Role of Lead Market Factors in Globalization of Innovation: Emerging Evidence from India and its Implications", in: P. Wesling, et al (eds.): Advances in Technology and Innovation Management, Volume 1, Santa Clara: IEEE, 189-199.

Tiwari, R. and C. Herstatt (2012): "Assessing India's Lead Market Potential for Cost-effective Innovations", in: Journal of Indian Business Research, 4(2): 97-115.

Tiwari, R. (2012): "Indian Investments in Germany: A Win-Win Proposition", in: Annual Review 2012, Indo-German Chamber of Commerce, pp. 123-125, Mumbai.

Tiwari, R. (2012): "Smart Mobility for India: Needs, Opportunities and Challenges", in: GermanyContact India, Issue 02/2012 (August), pp. 16-17.

Tiwari, R. and C. Herstatt (2012): "India - A Lead Market for Frugal Innovations? Extending the Lead Market Theory to Emerging Economies", Working Paper No. 67, Hamburg: Institute for Technology and Innovation Management, Hamburg University of Technology.

Tiwari, R., Herstatt, C., and Ranawat, M. (2011): Benevolent Benefactor or Insensitive Regulator? Tracing the Role of Government Policies in the Development of India's Automobile Industry, in: Policy Studies, No. 58, Honolulu: East West Center.

Buse, S., Tiwari, R., and Herstatt, C. (2010): Global Innovation: An Answer to Mitigate Barriers to Innovation in Small and Medium-sized Enterprises, in: International Journal of Innovation and Technology Management, Volume: 7, Issue: 3, pp. 215-227.

Tiwari, R. and Herstatt, C. (2010): The Emergence of Indian Multinational Enterprises: An Empirical Study of the Motives, Current Status, and Trends of Indian Investment in Germany, in: Karl P. Sauvant, et al (eds.): The Rise of Indian Multinationals: Perspectives on Indian Outward Foreign Direct Investment, New York: Palgrave Macmillan, pp. 233-253.

Tiwari, R. (2010): Indische Unternehmen in Deutschland: Motive, Erfahrungen und Herausforderungen, in: Erich G. Fritz (Hrsg.): Entwicklungsland, Schwellenland, Global Player: Indiens Weg in die Verantwortung, Oberhausen: ATHENA-Verlag, pp. 167-177.

Herstatt, C., Tiwari, R., Ernst, D., and Buse, S. (2008): India's National Innovation System: Key Elements and Corporate Perspectives, Working Paper No. 96, Economic Series, Honolulu: EastWest Center.

Tiwari, R., Buse, S., and C. Herstatt (2007): Innovation via Global Route: Proposing a Reference Model for Chances and Challenges of Global Innovation Processes, in: Proceedings of the Second International Conference on Management of Globally Distributed work, Bangalore, India.

Tiwari, R. (2007): The Early Phases of Innovation: Opportunities and Challenges of Public-private Partnerships, in: Asia Pacific Tech Monitor, Vol. 24, No. 1, pp. 32-37. 


\section{About Institute for Technology and Innovation Management}

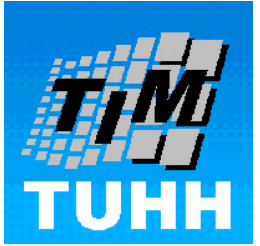

The Institute for Technology and Innovation Management at the Hamburg University of Technology (TUHH) was founded in 1998 and is headed by Prof. Cornelius Herstatt PhD, MBA. Prof. Herstatt has worked for many years in managerial positions in both Industry and Consulting. Before joining TUHH, he was teaching at the University of Zurich and St. Gall (Switzerland). The department is still in the building-up phase, and we cooperate with a number of research institutes in and outside of Germany as well as with a number of companies and federal/private institutions.

At our institute we take care of both, education in various fields of business administration (e.g. Innovation Management, Marketing and Sales, Project Management, etc.), and dedicated research in the field of Technology and Innovation Management.

We see ourselves as an open institute that develops and later transfers knowledge, mostly in close cooperation with companies and institutions. In our research, we focus on the management of the innovation process in both the classical ("old") economy and the service sector. The product-creation process, its organizational and instrumental aspects are the umbrella of our various research projects. The underlying goal of all these projects is the identification and analysis of strategic and operational issues which have a major influence on the eventual success of innovation. Through cooperations with companies we carry out research projects or market studies. We offer advice through consulting projects and develop seminars, workshops and trainings.

Webpage: www.tuhh.de/tim

\section{About Research Project Global Innovation}

'Global Innovation' is a research project of the Institute of Technology \& Innovation Management (TIM) at Hamburg University of Technology (TUHH). A primary aim of this project is to observe, analyze and forecast developments in the field of globalization of innovations. It also aims to provide decision-makers from selected industry sectors with useful instruments while deciding on whether or not to internationalize their innovation / R\&D activities and to which locations.

Even though not exclusively focussed on a single region, the research project pays special attention to emerging R\&D locations such as China and India.

Webpage: $\underline{\text { www.global-innovation.net }}$ 


\section{About the Authors}

Prof. Dr. Cornelius Herstatt is the Director of the Institute for Technology and Innovation Management (TIM) at the Hamburg University of Technology in Germany (TUHH). He is a founding partner of the European Institute for Technology and Innovation Management. Prof. Herstatt has published extensively on innovation and technology management. He can be reached at c.herstatt@tuhh.de.

Rajnish Tiwari is a Research Associate at TIM/TUHH. India's emergence as an "innovation hub" plays a central role in his research on lead markets and globalization of innovation. He has written various papers on innovation by domestic and global firms based in India. Overseas investments by Indian firms, Indo-German economic relations, and Mobile Commerce applications are further areas of his research. He can be reached at tiwari@tuhh.de. 